\title{
Active venting sites on the gas-hydrate-bearing Hikurangi Margin, off New Zealand: Diffusive- versus bubble-released methane
}

\author{
Lieven Naudts $^{\mathrm{a}, *}$, Jens Greinert ${ }^{\mathrm{a}, \mathrm{b}}$, Jeffrey Poort ${ }^{\mathrm{a}, \mathrm{c}}$, Joke Belza ${ }^{\mathrm{a}}$, Elke Vangampelaere ${ }^{\mathrm{a}}$, Dries Boone ${ }^{\mathrm{a}}$, \\ Peter Linke ${ }^{\mathrm{d}}$, Jean-Pierre Henriet ${ }^{\mathrm{a}}$, Marc De Batist ${ }^{\mathrm{a}}$ \\ a Renard Centre of Marine Geology (RCMG), Universiteit Gent, Krijgslaan 281 s8, B-9000 Gent, Belgium \\ ${ }^{b}$ Royal Netherlands Institute for Sea Research (NIOZ), P.O. Box 59, 1790 AB, Den Burg (Texel), The Netherlands \\ c Laboratoire de Géosciences Marines, Institut de Physique du Globe de Paris (IPGP) 4, place Jussieu, 75005 Paris, France \\ d Leibniz-Institut für Meereswissenschaften IFM-GEOMAR, Wischhofstrasse 1-3, D-24148 Kiel, Germany
}

\section{A R T I C L E I N F O}

\section{Article history:}

Received 12 January 2009

Received in revised form 21 July 2009

Accepted 6 August 2009

Available online 15 August 2009

Communicated by G.J. de Lange

\section{Keywords:}

methane seeps

ROV

Hikurangi Margin

sea-floor observations

temperature measurements

bubble-release activity

\begin{abstract}
A B S T R A C T
During the 'New Vents' S0191 cruise in 2007, the activity and distribution of seep sites on the gas-hydratebearing Hikurangi Margin, off northeastern New Zealand, were subjected to a highly detailed interdisciplinary study. Here we report on the visual observations and in situ measurements of physical properties performed with a ROV (remotely operated vehicle) and other video-guided platforms at two seep sites in the Rock Garden area; Faure Site and LM-3. The ROV allowed first ever visual observations of bubblereleasing methane seeps at the Hikurangi Margin. At Faure Site, bubble release was monitored during 4 dives, up to periods of 20 min. During the first dive, this resulted in the observation of six violent outbursts, each lasting 1 min over a three minute interval. These outbursts were accompanied by the displacement and resuspension of sediment grains, and the formation of small depressions, with a maximum diameter of $50 \mathrm{~cm}$ and depth of $15 \mathrm{~cm}$, showing what is possibly an initial stage of pockmark formation. During subsequent dives at this bubble site, bubble release rates were rather constant and the previously observed outbursts could no longer be witnessed. At LM-3, the strongest manifestation of seep activity was a large platform $\left(100 \mathrm{~m}^{2}\right)$, consisting of fresh authigenic carbonates, which was covered by seep fauna (live Bathymodiolus sp. mussels, Calyptogena sp. shells and live Lamellibrachia sp. tubeworms). Bubble activity near this platform was less prominent than at Faure Site. Our observations suggest that the two seep environments result from different types of methane release; mainly by bubble release at Faure Site and rather diffusive at LM-3. We propose a conceptual model where the different ways of methane release and seep environments may be explained by the depth of underlying hydrate occurrences and different tectonic histories of both seep sites.
\end{abstract}

(c) 2009 Elsevier B.V. All rights reserved.

\section{Introduction}

Gas seeps, i.e. locations of bubble release at the sea floor, are widespread on continental margins (Judd, 2003; Judd and Hovland, 2007). Their presence is commonly indicated by anomalies that are visible on different types of acoustic data, such as seismics, singlebeam or multibeam echosounder or side-scan sonar (Greinert et al., 2006; Klaucke et al., 2006; Naudts et al., 2006; Schneider von Deimling et al., 2007; Gay et al., 2007; Judd and Hovland, 2007; Naudts et al., 2008; Greinert, 2008). While acoustic data are very useful to identify areas in which seeps occur, they usually fail to pinpoint the exact location of bubble release at the sea floor on meter or sub-meter scale. Seeps are often associated with distinct ecosys-

\footnotetext{
* Corresponding author. Tel.: +32 92644584; fax: +32 92644967. E-mail address: Lieven.Naudts@UGent.be (L. Naudts).
}

tems with chemosynthetic fauna (bacterial mats, clams, tubeworms etc.) (Boetius and Suess, 2004; Judd and Hovland, 2007). Furthermore, seeps are often characterized by the presence of authigenic carbonates, which are easy to identify during near-bottom investigations, even without bubble release during the observations (Hovland et al., 1985; Paull et al., 1992; Peckmann et al., 2001; Orange et al., 2002; Greinert et al., 2002a; Judd and Hovland, 2007; Naudts et al., 2008). A very good method to observe and study seeps, their activity and the associated ecosystems is by detailed, visual, sea-floor observations in possible seep areas indicated by acoustic investigations.

Visual sea-floor observations can be made with a towed video sled, a manned submersible or a remotely operated vehicle (ROV). Towed video sleds make it possible to gain a regional overview of the seafloor features by criss-crossing a target area (Greinert et al., 2002b; Sahling et al., 2008; Naudts et al., 2008). However, with video sleds it is not possible to stay on position, to move within small areas, to take samples or to perform measurements at a certain position over longer 


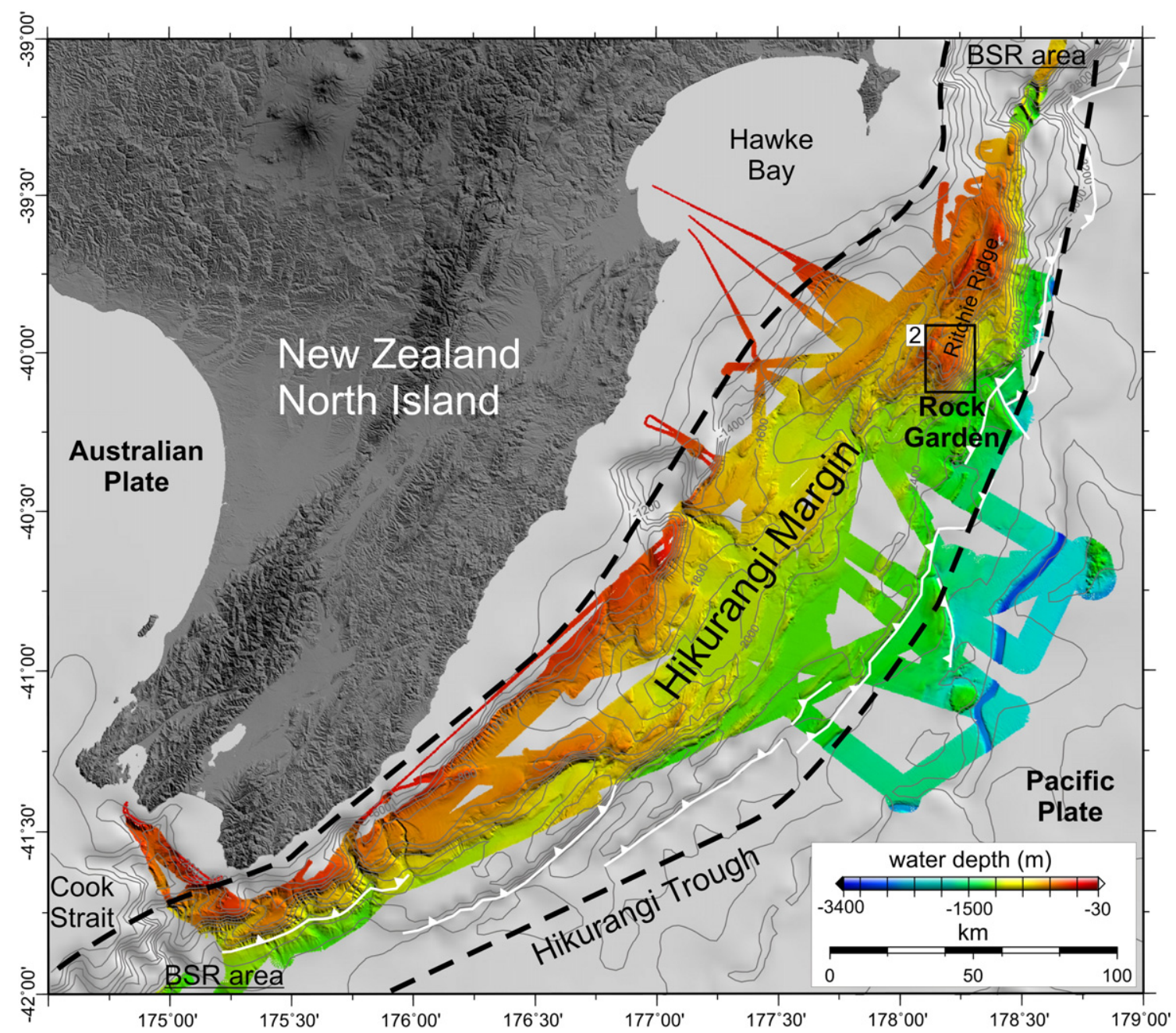

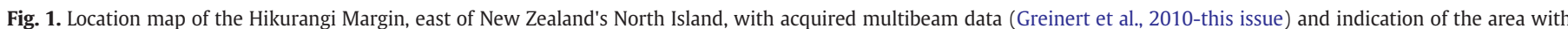

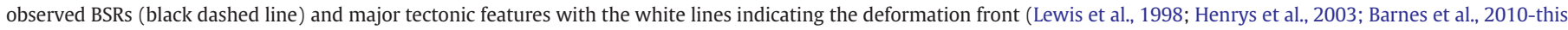
issue). Outline for Fig. 2 is also given. Land topography is derived from Shuttle Radar Topography Mission (SRTM) data. The bathymetry data is courtesy of NIWA.

time. Manned submersibles have the disadvantage that they are commonly very large and require a large ship and specialized crew. By contrast, ROVs are more adapted and have been used extensively in the last decade to study seep areas (Fujikura et al., 1999; Coleman and Ballard, 2001; Hovland, 2002; Orange et al., 2002; Ondréas et al., 2005; Paull et al., 2005; Sauter et al., 2006; Gay et al., 2006; Paull et al., 2007; Jerosch et al., 2007; Olu-Le Roy et al., 2007; Judd et al., 2007; Nikolovska et al., 2008).

In this paper, we present the first ever visual observations of bubble-releasing seeps at the Hikurangi Margin. In 2007, ROV and video-guided deployments enabled us to precisely locate the active methane seeps on the margin, and to perform detailed sea-floor observations, measurements and sampling at and around the seeps. Moreover, the use of ROV 'GENESIS' allowed us to investigate shortterm temporal variations in seep activity, alternating from almost complete inactivity to violent outbursts, and to estimate bubblerelease rates and methane flow rates.

\section{Study area}

The Hikurangi Margin, on the east side of New Zealand's North Island, is an accretionary margin related to the oblique subduction of the Pacific Plate underneath the Australian Plate (Barnes et al., 2010this issue) (Fig. 1). Several areas with methane seeps and with bottomsimulating reflections (BSRs) visible on seismic recordings, possibly indicating the presence of gas hydrates, have already been described along this margin (Katz, 1982; Townend, 1997; Henrys et al., 2003; Pecher et al., 2004; Pecher et al., 2005; Faure et al., 2006; Greinert et al., 2010-this issue; Crutchley et al., 2010-this issue).

Here, we focus on Rock Garden, which is the southern termination of Ritchie Ridge, as our study area on the Hikurangi Margin, (Figs. 1 and 2). Rock Garden is an informal name, given by local fishermen, and refers to its rocky sea floor (Faure et al., 2006). The origin of Rock Garden's flattopped relief and its uplift is still under debate. The uplift may be related to the subduction of a seamount or to major subduction-related thrust

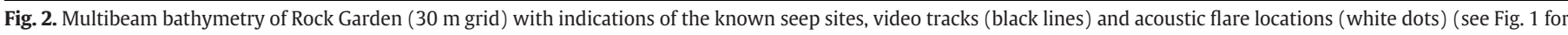

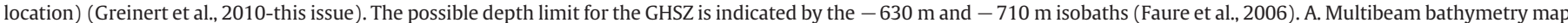

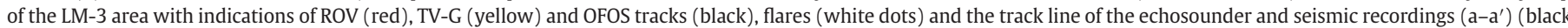

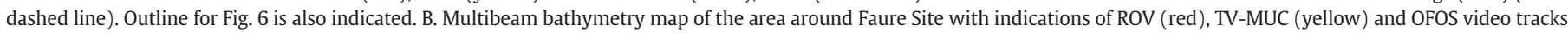
(black), flares (white dots) and the track lines of the echosounder (b-b') and seismic recording (c- $\mathrm{c}^{\prime}$ ) (black dashed lines). Outline for Fig. 8 is also indicated. 


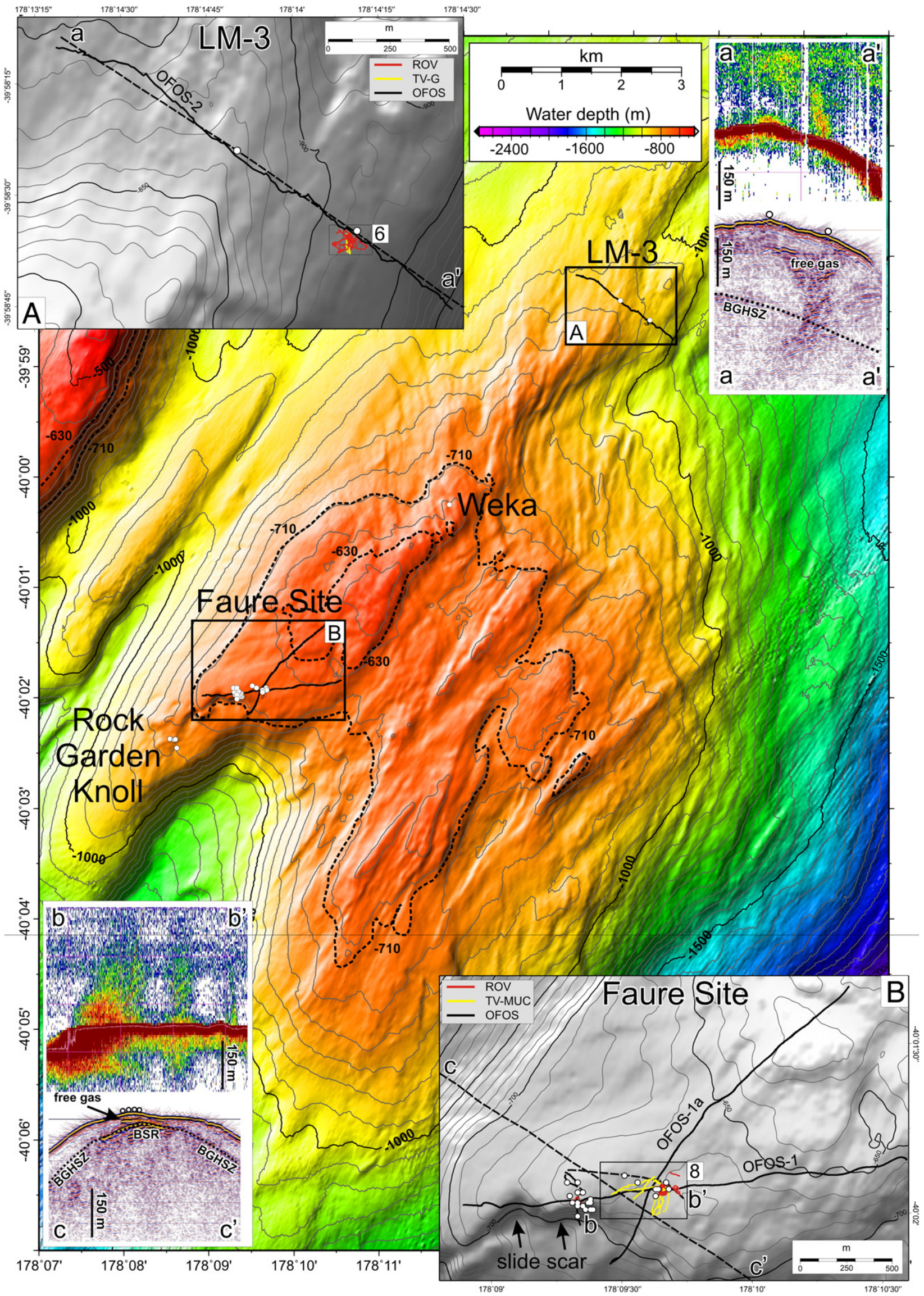


faults, perhaps in relation to gas hydrate dissociation (Pecher et al., 2004; Barnes et al., 2010-this issue; Ellis et al., 2010-this issue). Gas hydrates are suspected to be present at Rock Garden, even at shallow subsurface depths. This is based on several BSR observations and a calculated hydrate stability zone (HSZ) for pure methane hydrates, starting at water depths between 630 and $710 \mathrm{~m}$ (Pecher et al., 2004; Pecher et al., 2005; Faure et al., 2006; Ellis et al., 2010-this issue; Crutchley et al., 2010-this issue). However, they have never been sampled in Rock Garden, partially due to its rocky sea floor which makes gravity coring highly difficult. Since the water depth at Rock Garden ranges from 579 to $1100 \mathrm{~m}$, pure methane hydrates are theoretically not stable in the shallowest areas, as is also indicated by BSR pinch outs towards the ridge crest (Pecher et al., 2005; Crutchley et al., 2010-this issue). Seismic data indicate the presence of shallow free gas above the base of the gashydrate stability zone (BGHSZ) (Fig. 2) (Crutchley et al., 2010-this issue). Two such shallow gas occurrences in Rock Garden are associated with the observation on echograms of vertical acoustic anomalies rising from the sea floor into the water column (Crutchley et al., 2010-this issue). These anomalies are caused by rising gas bubbles and are hereafter referred to as "flares". These two seep sites, here called "Faure Site" and "LM-3", are the main targets of this study (Lewis and Marshall, 1996; Faure et al., 2006; Crutchley et al., 2010-this issue) (Fig. 2).

LM-3, referring to "seep site 3" as described by Lewis and Marshall (1996), is located in the northern part of Rock Garden (Fig. 2). In 1994, fishermen observed a flare on a fish-finder echosounder there and retrieved live bivalves (Bathymodiolus sp.) and a small piece of carbonate chimney. Subsequent sampling resulted in the retrieval of chemosynthetic fauna (empty vestimentiferan tubes, Calyptogena sp. and Bathymodiolus sp. valves) as well as the observation of an acoustic flare, rising $250 \mathrm{~m}$ above the sea floor (Lewis and Marshall, 1996).

Faure Site, referring to the seep site discovered by Faure et al. (2006), is located in the western part of Rock Garden (Fig. 2). During the 2004 TAN0411 survey, an acoustic flare and a localized geochemical methane anomaly in the water column were observed at this site, near the scarp of a submarine landslide (Pecher et al., 2005; Faure et al., 2006). Pecher et al. (2005) proposed that the submarine landslide is caused by gas-hydrate-induced 'frost heave', driven by fluctuations of bottom-water temperatures and pressures.

In 2006 during the subsequent TAN0607 survey, seismic and single-beam recordings, as well as water sampling confirmed LM-3 and Faure site as active seep sites (Fig. 2) (Crutchley et al., 2010-this issue; Faure et al., 2010-this issue).

\section{Methods and data}

\subsection{Single-beam seep detection}

Due to the high impedance contrast between water and free gas, gas bubbles rising in the water column can be acoustically detected by means of single-beam echosounder recordings. They show up as "acoustic flares" on echograms (Naudts et al., 2006; Greinert et al., 2006; Artemov et al., 2007). The seep locations in this study, were determined from single-beam echosounder records acquired during two cruises with RV TANGAROA (TAN0607 and TAN0616) in 2006 (Fig. 2). For further information see Greinert et al. (2010-this issue).

\subsection{Multibeam mapping}

The multibeam bathymetry and backscatter data were acquired during the SO191 expedition with RV SONNE in January-March 2007 (SIMRAD EM120; $20 \mathrm{kHz}$ ) and during two surveys with RV TANGAROA (TAN0607 and TAN0616) in 2006 (SIMRAD EM300; 30 kHz) (Fig. 2). Depending on the size of the displayed area, the grid sizes vary between $150 \mathrm{~m}$ and $10 \mathrm{~m}$. Backscatter data processing was done with the FMGeocoder software from IVS3D. For further information about the multibeam mapping see Greinert et al. (2010-this issue).

\subsection{Visual observations}

\subsubsection{ROV 'GENESIS'}

During the SO191-3 expedition seven dives with ROV 'GENESIS' were carried out to localize, to observe, to map and to perform measurements at methane seeps on the Hikurangi Margin. ROV 'GENESIS' is owned and operated by RCMG-UGENT (Renard Centre of Marine Geology-Ghent University). The main focus was Rock Garden, with two dives at LM-3 (Lewis and Marshall, 1996) and four dives in the vicinity of Faure Site (Faure et al., 2006). The ROV is a sub-Atlantic CHEROKEE ROV that was operated in TMS (Tether Management System) mode. The TMS is a metal frame that contains the ROV during the descent to the ocean floor and a cable of $200 \mathrm{~m}$ (tether). The ROV was equipped with a forward-looking color video camera, a black-andwhite video camera and one backward-looking black-and-white video camera. For object detection (e.g. bubbles) a forward-looking 'Super Seeking Sonar System' ( 325 or $675 \mathrm{kHz}$ ) was used. Accurate positioning and navigation of the ROV was achieved through the use of an USBL (ultra-short baseline) positioning system, consisting of a ship-mounted IXSEA GAPS and a ROV-mounted IXSEA transponder. The OFOP (Ocean Floor Observation Protocol) software package was used to navigate the ROV, store ROV parameters and make preliminary sea-floor characterization in real time (Huetten and Greinert, 2008). OFOP was also used for post-cruise navigation processing, video replay and sea-floor characterization. At Faure Site, 1385 m of ROV video tracks were recorded during 4 h18' of effective survey time. At LM-3, $2213 \mathrm{~m}$ of ROV video tracks were recorded in $3 \mathrm{~h} 23^{\prime}$.

\subsubsection{OFOS, TV-MUC and TV-G}

In addition to the video records from the ROV, visual sea-floor observations also were acquired with an OFOS (Ocean Floor Observation System) video sled, a TV-MUC (TV-guided multi-corer) and a TV-G (TVguided grab). The OFOS was equipped with downward-looking color and monochrome CCD (charge-coupled device) video cameras, a 4 megapixel stills camera and a memory CTD (conductivity-temperature-depth sensor). The scale of the images, as well as the height of OFOS above the sea floor, was visually indicated by an array of three red lasers. The distance between the two outer lasers is $20 \mathrm{~cm}$. The TV-MUC and TV-G are sediment sampling devices that both use a camera for realtime selection of sampling sites. Positioning and navigation of OFOS, TVMUC and TV-G was done by either a SIMRAD DHT 163 system, or one of the two IXSEA systems (POSIDONIA or a GAPS), depending on availability during the cruise. The OFOP software package was used in a similar way as for the ROV dives. Mosaics of video sequences were made with IFREMER's ADELIE software package.

\subsection{Measurements of physical properties}

The ROV also was equipped with a stand-alone memory FSI CTD, a NKE THP (THermoProbe) temperature sensor and two Niskin bottles. The CTD was mounted on the ROV at ca. $50 \mathrm{~cm}$ from the base of the ROV, while the THP temperature sensor was operated using the manipulator arm in order to allow penetration within the sediments. The temperatures measured with the CTD and the THP sensors have accuracies of $0.002{ }^{\circ} \mathrm{C}$ and $0.007^{\circ} \mathrm{C}$, respectively. Water samples from the Niskin bottles were used to obtain dissolved methane concentrations and $\delta^{13} \mathrm{C}_{\mathrm{CH}_{4}}$ values (Faure et al., 2010-this issue).

\section{Observations and results}

\subsection{Regional sea-floor observations}

\subsubsection{Northern Rock Garden: LM-3}

During OFOS-2 video survey, the northern extent of Rock Garden was surveyed in NW-SE direction, hereby crossing the LM-3 site (Figs. 2A and 3). The sea floor is generally hard and covered by a thin 


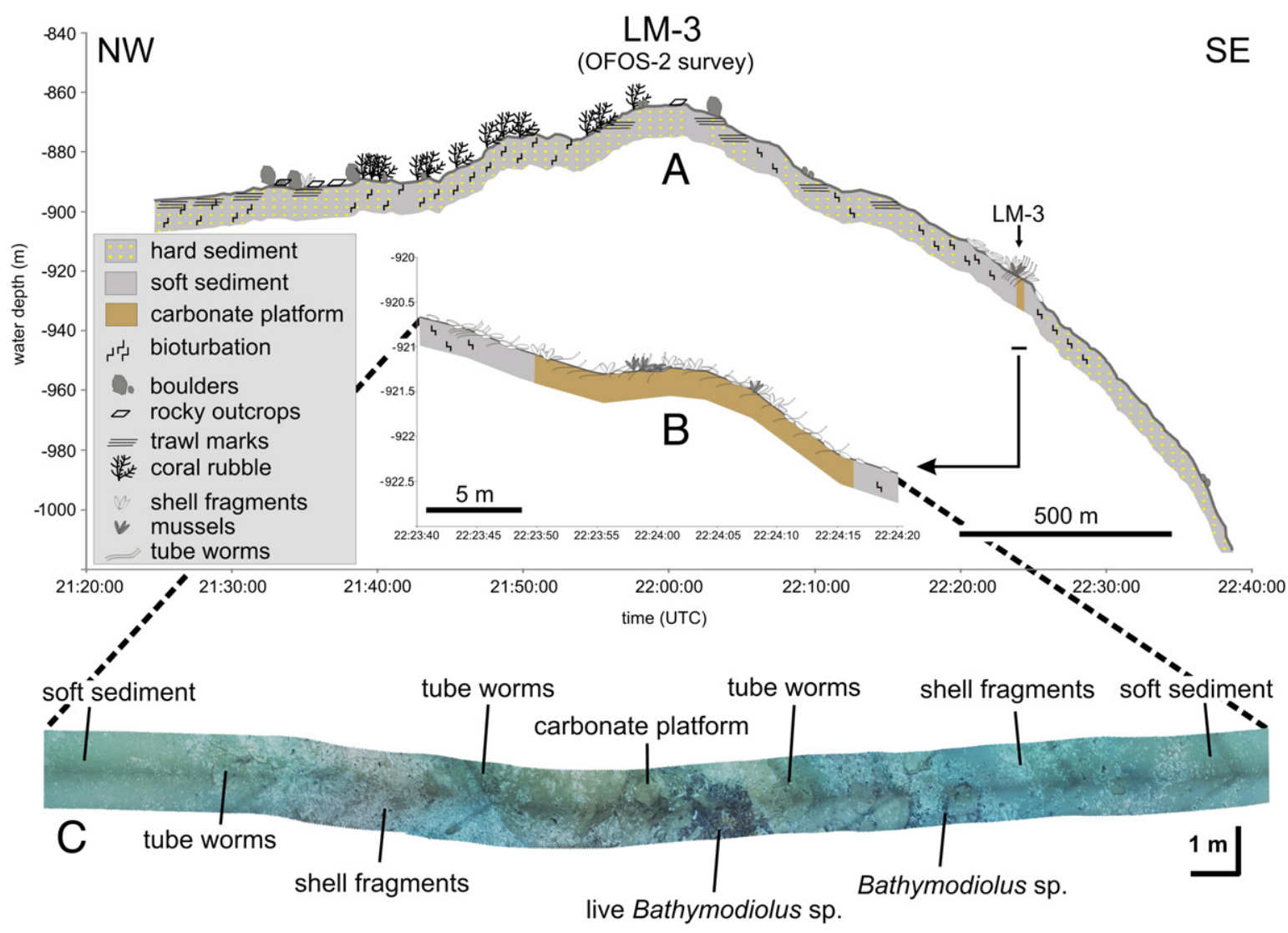

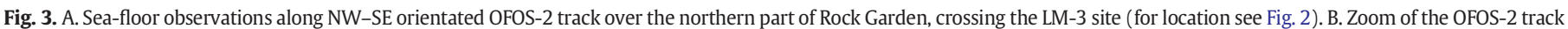
over the LM-3 site. C. Video mosaic created with ADELIE software from the OFOS-2 video sequence over the LM-3 site. Video mosaic shown in C corresponds to the track shown in B.

drape of bioturbated hemipelagic sediments, alternating with softsediment areas, boulders and rocky outcrops (Figs. 3 and 4). The sea floor on the western flank of the NE-SW trending ridge is often covered by deep-water coral rubble (Figs. 2 and 4C). Trawl marks are visible as linear features in areas shallower than $900 \mathrm{~m}$ water depth (Fig. 3). LM-3, located on the east side of the ridge, is a very small area consisting of a platform-like structure, composed of authigenic carbonate rocks, within an area of softer sediments covered by shell fragments (Calyptogena sp.) (Figs. 3 and 4A-B) (Campbell et al., 2010this issue). The area around the platform-like structure is the only area in which dense fields of shell fragments (Calyptogena sp.) were observed, sometimes in association with scattered dead bivalves (Bathymodiolus sp.) and/or vestimentiferan tubeworms (Lamellibrachia sp.) (Fig. 3). Live Bathymodiolus sp. bivalves were only observed on top of the platform (Figs. $3 \mathrm{C}$ and $4 \mathrm{~A}$ ). No bubble-releasing seeps were observed during OFOS-2 survey.

\subsubsection{Western Rock Garden: Faure Site}

During OFOS-1 and OFOS-1a video surveys, the western extent of Rock Garden was surveyed in W-E and NE-SW directions respectively, thereby crossing Faure Site (Figs. 2B and 5). The sea floor generally consists of bioturbated soft sediments alternating with small built-up, platform-like features or outcrops (Figs. 4D-F and 5). The elevated areas are rockier with boulders and rocky outcrops, often in association with coral rubble (Figs. 4F-H and 5). Calyptogena sp. shell fragments are widespread, but no live clams or mussels were observed. At Faure Site, the sea-floor morphology is relatively uniform with large platform-like structures in the western part of the investigated area. These structures are associated with vestimentiferan tubeworms (Lamellibrachia sp.) and sometimes with great amounts of shell fragments (Calyptogena $s p$.) (Figs. 4E and 5A). This area forms the transition to a slide scarp, with rocky outcrops and occurrences of coral rubble and shell fragments (Figs. 2, 4H and 5A). No bubbling seeps were observed during OFOS-1 and OFOS-1a surveys.

\subsection{Local sea-floor observations}

\subsection{1. $L M-3$}

Based on the regional reconnaissance during OFOS-2 survey, an area was selected for local sea-floor observations during ROV-4 and ROV5 dives, and subsequent sampling during TV-G-17 survey at LM-3 (Figs. 2 and 6). The $10,000 \mathrm{~m}^{2}$ area surveyed with the ROV generally consists of bioturbated sandy sediments covered by shell fragments (Calyptogena sp.) surrounding the platform-like structure (Figs. 6 and 7). The platform has an extent of $100 \mathrm{~m}^{2}$ and consists of large blocks, which form a pavement-like structure with a distinct positive relief (Figs. 6B and 7A-C). The cracks in between the large blocks are filled with live Bathymodiolus sp. mussels, live Lamellibrachia sp. tubeworms and some Calyptogena sp. shells. The live Bathymodiolus sp. mussels only occur on top of the platform, whereas Calyptogena sp. shell hashes occur in the depressions surrounding the platform (Figs. 6C-E and 7A-C and E). Small sponges and soft-tissue corals also cover the top of the platform (Figs. 6F and 7A-C). The multibeam bathymetry shows that the platform occurs on the transition from a flat (ca. 1\%) to a steeper (ca. $10 \%$ ) sloping sea floor (Fig. 6A). This transition is associated with one of the major thrust faults in Rock Garden (Fig. 2) (Barnes et al., 2010-this issue). The platform location also corresponds to a patch of highbackscatter seen in the multibeam-backscatter data (Figs. 6B-F). During ROV-4 and TV-G-17 surveys bubble release was observed at two sites south of this platform, just at the border of the high-backscatter area (Figs. 6B-F and 7E-F). Between these two active seep sites and close to a Calyptogena sp. shell hash, a peculiar spotted micromorphology is 

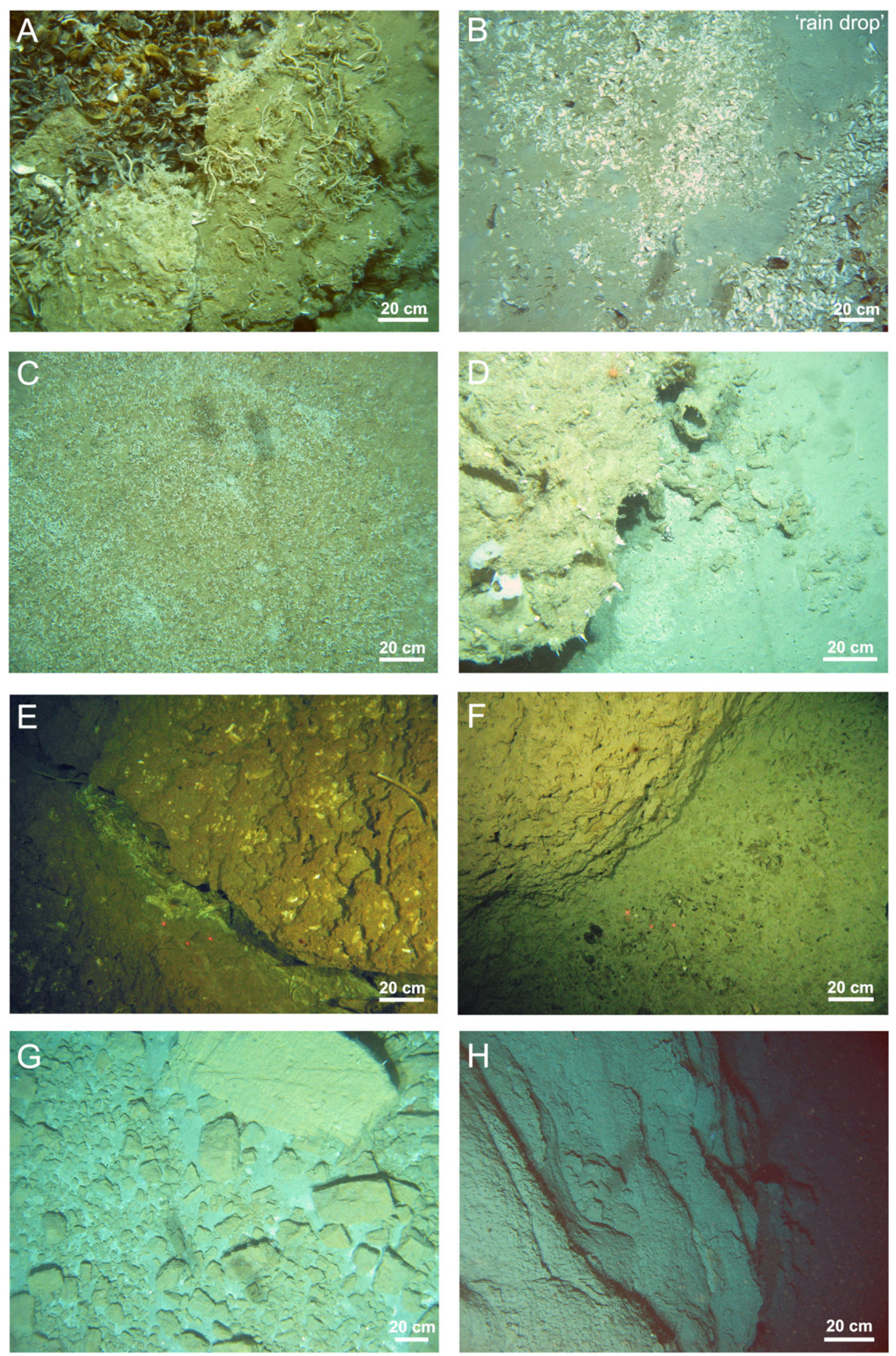

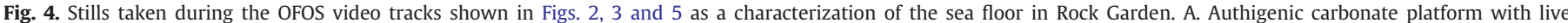

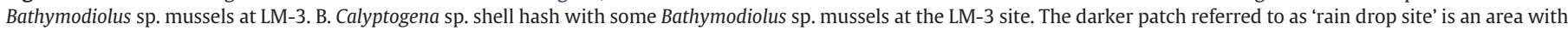

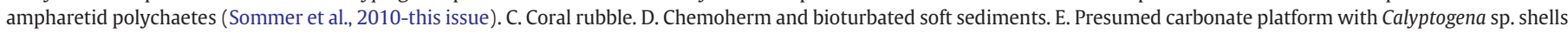
and a tubeworm from the area west of the Faure Site. F. Semi-indurated outcrops at the Faure Site. G. Boulders H. Rocky outcrop from the slide scarp west of the Faure Site. 

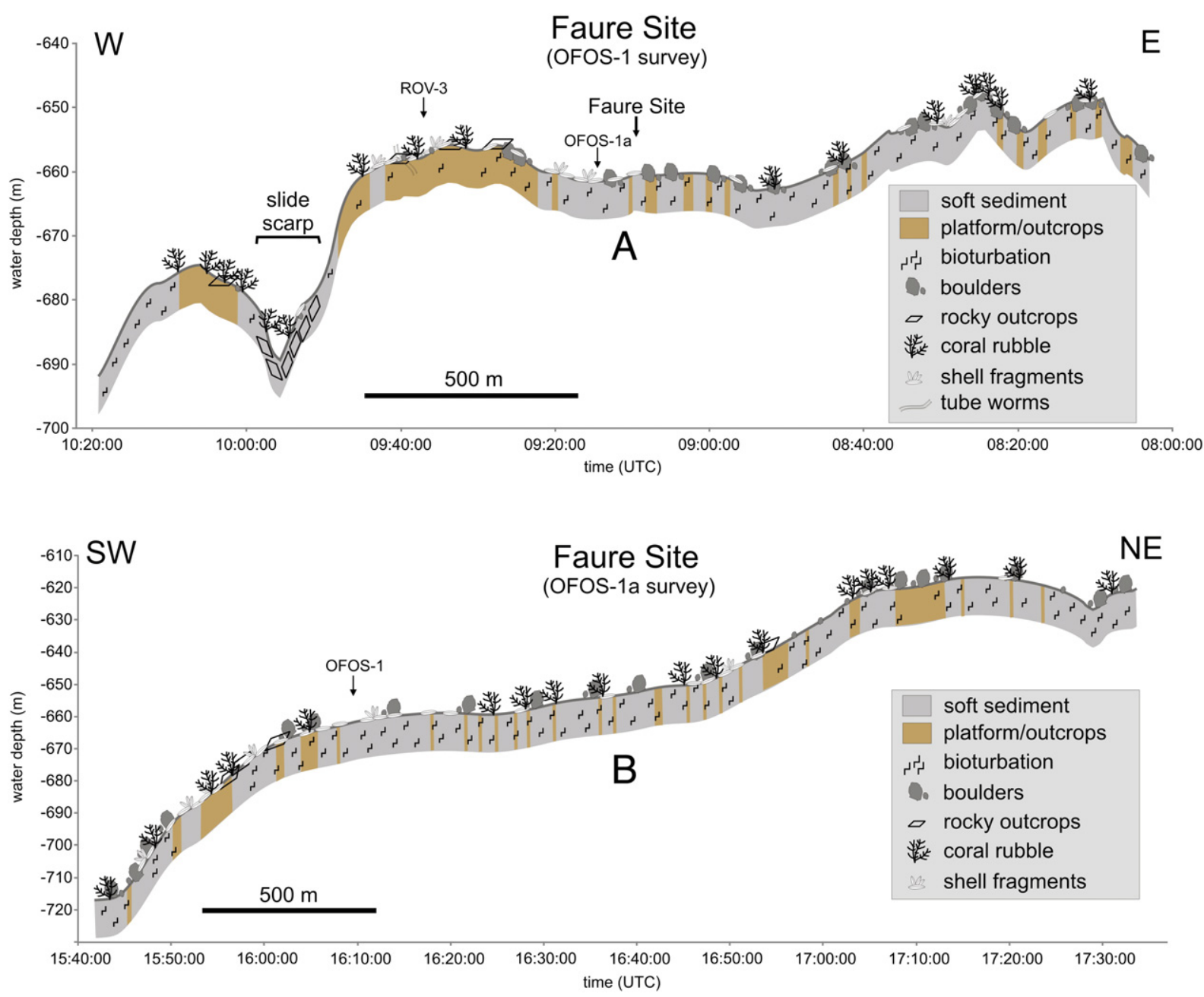

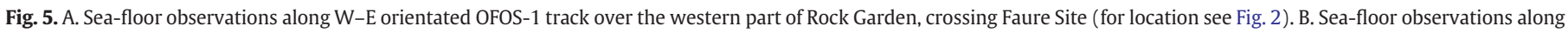
NE-SW orientated OFOS-1a track over the western part of Rock Garden, crossing Faure Site (for location see Fig. 2). The crossing point of the two tracks is indicated in A and B.

present, referred to as 'rain drop site' (Figs. 4B and 6C-F). The name 'rain drop site' refers to the characteristic sea-floor appearance of a polychaete bed (Sommer et al., 2010-this issue). Sampling shows that the sea-floor sediments from this area are densely populated by ampharetid polychaetes which form small, crater-like depressions in the sea floor. The bubble-releasing seep site observed during ROV-4 dive is located closest to the platform, in between Calyptogena sp. shell hashes, and consists of a single bubble-releasing outlet (Figs. 6 and 7E). The seep site observed during TV-G-17 survey is located further away from the platform and consists of 5 different bubble-releasing outlets. Here bubbles are released from sandy sediments covered by a small amount of shell fragments (Figs. 6 and 7F). These observations agree with the general perception that the sea floor further away from the platform is covered with smaller amounts of shell fragments (Calyptogena sp.). At about $100 \mathrm{~m}$ from the platform, the sea floor also changes from soft and sandy to hard and sediment-starved. Within the soft sandy area, several large depressions occur (dm-scale), which clearly differ from the small holes (cm-scale) generally attributed to bioturbation (see difference between Figs. 4D and 7D). These large depressions are often accompanied by small hills, giving a hummocky appearance to the sea floor. No bubble release was observed from these depressions at LM-3.

\subsubsection{Faure Site}

Based on Faure et al. (2006) and the single-beam seep detection performed during the TAN0607 cruise in 2006, the Faure Site was studied during the ROV-2, ROV-3, ROV-6 and ROV-7 dives. The first dive
(ROV-2) resulted in the first ever visual observation of bubble-releasing seeps at the Hikurangi Margin and in the subsequent ROV, TV-MUC and lander deployments (Figs. 8 and 9). The 20,000 $\mathrm{m}^{2}$ area surveyed with the ROV generally consists of bioturbated sandy sediments alternating with strongly eroded outcrops (Figs. 8B and 9A-C). These outcrops stand a couple of decimeters in relief and are semi-indurated, which made it impossible to sample them with the ROV's claw, and to determine their nature (Figs. 9A-B). Shallow subsurface presence of the rock formations was confirmed by the observations made during ROV-6, which showed that the sediment chambers from both landers were only able to penetrate $11 \mathrm{~cm}$ into the sediment causing both landers to be tilted (Fig. 9D) (Linke et al., 2010-this issue). But again no rock samples could be taken for analysis. The depression-and-hill morphology, as seen at LM-3, is also very common at Faure Site (Fig. 9A-C). Shell fragments (Calyptogena sp.) are not widespread but are abundant around the active seep sites (red dots in Fig. 8) and in the area west of this site (Fig. 8C). Sessile fauna (corals, sponges) are abundant just east of the seep sites, at locations with boulders or rock debris. During all three ROV dives, bubble-releasing seeps were observed at Faure Site. The two main seep areas, ca. $20 \mathrm{~m}$ apart, were characterized by the occurrence of ampharetid polychaetes ('rain drop sites') and Calyptogena sp. shell fragments (Figs. 8C and 9D-F). Bubble release occurs from differently sized depressions which are often aligned in NW-SE direction; the largest depression observed, was $50 \mathrm{~cm}$ in diameter and $15 \mathrm{~cm}$ deep (Figs. 10C-D). Observations made during ROV-2 and ROV-7 clearly show that these depressions are formed by the often violent 

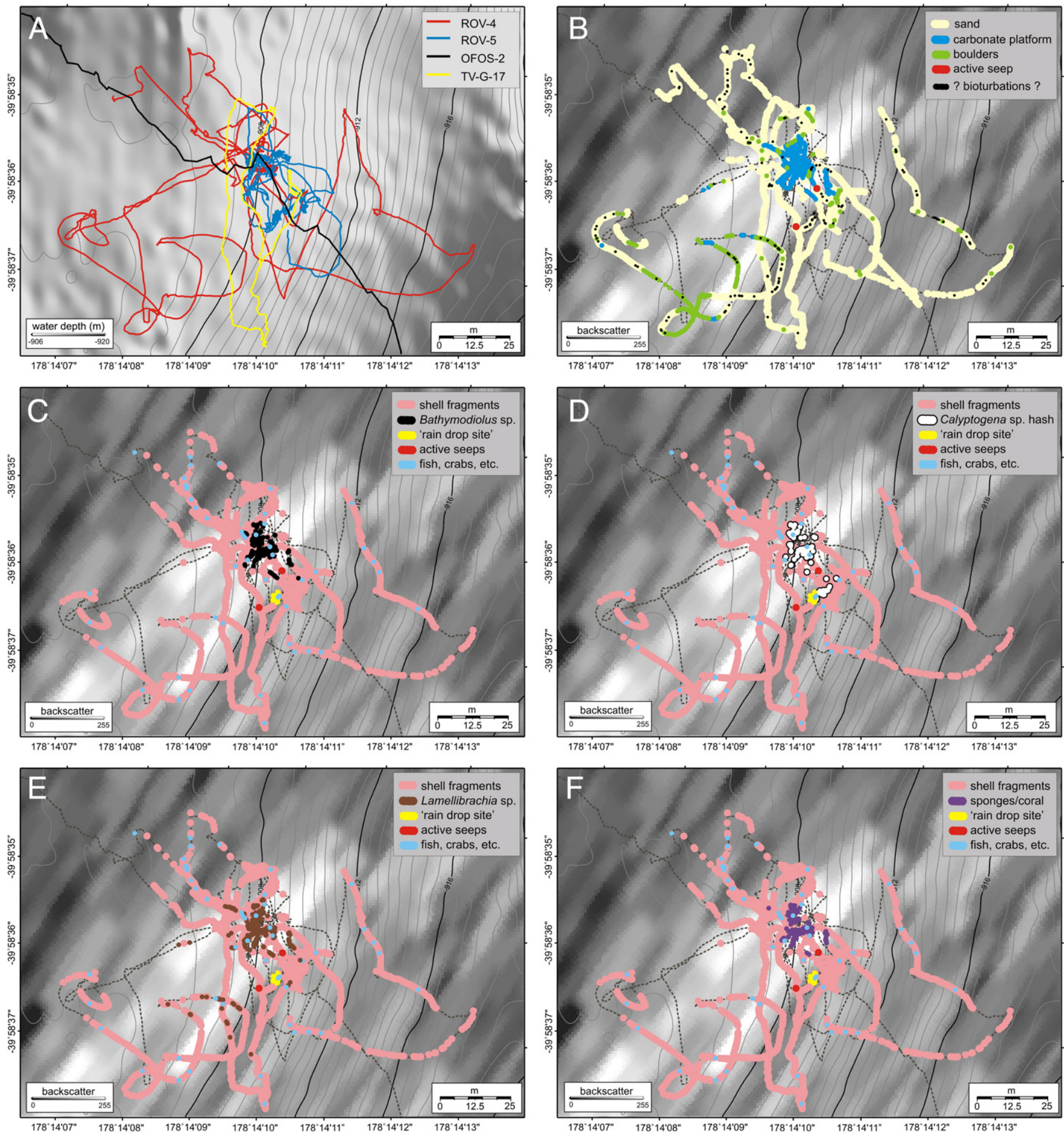

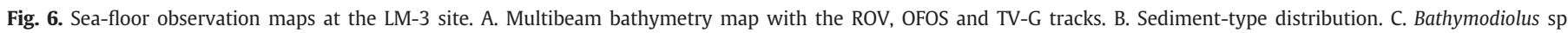

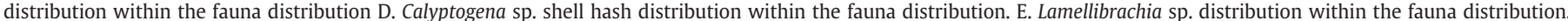
F. Distribution of sponges and soft tissue corals within the fauna distribution. B-F have multibeam backscatter as background.

release of bubbles. These bubbles entrain sediment particles, which then get carried away by the water currents, creating the depressions and a sediment outfall away from the venting holes (Figs. 9E and 10C-D). No active seeps were observed during the ROV-3 dive within the area near the top of the slide scarp where abundant flares were observed on echosounder recordings obtained during the TAN0616 cruise in 2006 (Fig. 2B). Nevertheless, the sea floor in this area is characterized by the widespread occurrence of platform-like structures or outcrops of presumably carbonate rocks, which are sometimes covered by Calyptogena sp. shell fragments and Lamellibrachia sp. tubeworms (Fig. 4E).

\subsubsection{Methane bubble-release rates}

Based on ROV video observations, we estimate the amount of methane released by bubbles at the different seep sites. At LM-3, the observation time was too short to approximate the size and the amount of the released bubbles. At Faure Site, 39 different bubbling seeps/outlets 

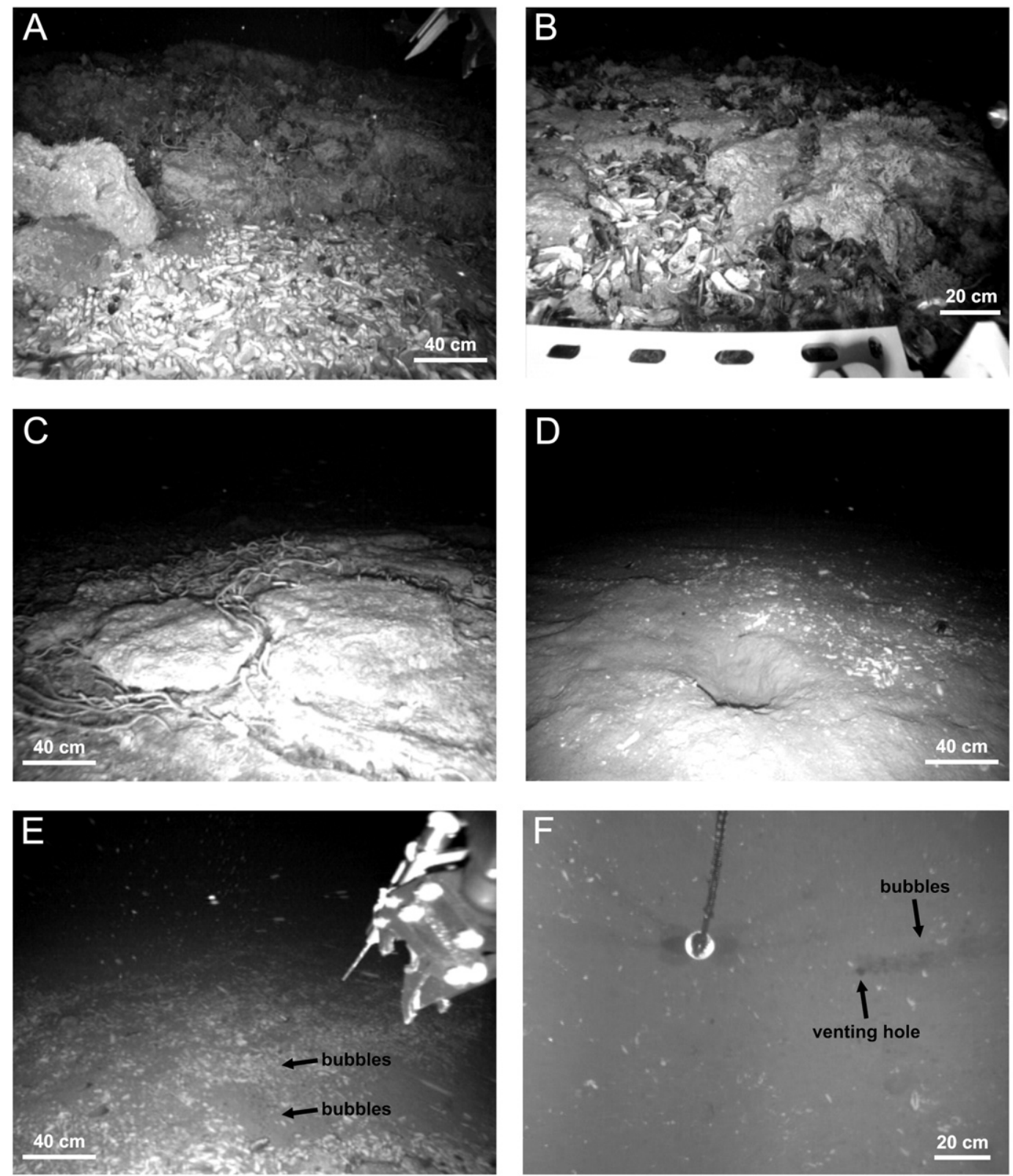

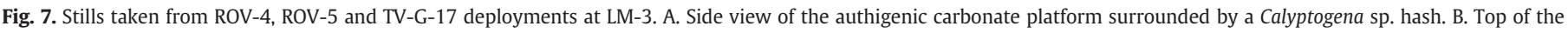

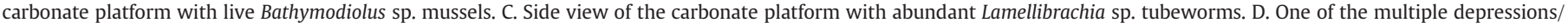
bioturbations observed at LM-3. E. Bubbling seep observed in-between shell hashes during ROV-4. F. Bubbling seep observed during TV-G-17.

could be observed in detail for up to $20 \mathrm{~min} /$ observation. These seeps are arranged in three main seep clusters located in two seep areas $20 \mathrm{~m}$ apart (red dots in Figs. 8B-C and 10E). During ROV-2 dive, bubble release was observed from 13 outlets in five depressions over a period of $20^{\prime 3} 9^{\prime \prime}$ (Fig. 10). During this period, bubble-release rates and bubble sizes were highly variable over time and space, with periods of low activity (i.e. 16 bubbles/s for bubbles of $6 \mathrm{~mm}$ diameter), alternating with periods of violent outburst (i.e. up to 190 bubbles/s for bubbles of $9 \mathrm{~mm}$ diameter) (Fig. 10). In total, six outbursts were observed, each starting violently and diminishing after 43 to 89 s (Fig. 10). Periods between the outbursts varied from 125 to $159 \mathrm{~s}$. During one of the outbursts seen in the ROV-2 dive (lasting $43 \mathrm{~s}$ with bubbles of $9 \mathrm{~mm}$ diameter), an in situ flow rate of $2.424 \mathrm{l} / \mathrm{min}$ was estimated, corresponding to a mole flow rate of $7.019 \mathrm{~mol}$ of methane/min, for in situ conditions of $7{ }^{\circ} \mathrm{C}$ and 67.45 bar (Fig. 10). During the following period of low activity ( $6 \mathrm{~mm}$ bubble), the flow rate was $0.163 \mathrm{l} / \mathrm{min}$, corresponding to $0.473 \mathrm{~mol}$ of methane/min. During the ROV- 6 dive, the latter seep cluster at Faure Site was revisited, i.e. southern seep area near FLUFO-4 (Figs. 8 and 9). However, no outbursts were observed during this dive, only changes in bubble-release rates and patterns over a period of 16'54" (Fig. 10 ROV-6B and ROV-6B'). Within this period, bubble rates were constant for at least $9^{\prime} 26^{\prime \prime}$ at ca. $5 \mathrm{~Hz}$ (two outlets), changing to ca. $22 \mathrm{~Hz}$ for 6' $14^{\prime \prime}$ (three outlets), before returning to $5 \mathrm{~Hz}$ (one outlet). Within the southern seep area a new seep cluster, consisting of three outlets, was found $5 \mathrm{~m}$ north of the previous cluster which was bubbling constantly during the $22^{\prime} 57^{\prime \prime}$ of observation (Figs. 8 , 9D and 10 ROV-6A). During ROV-7, more than 23 bubbling seeps were observed in one seep cluster, which constituted a new seep area $20 \mathrm{~m}$ to the north of the seep area observed during ROV-2 and ROV-6 (Fig. 10E). During a THP sediment-temperature measurement at a 'rain drop site', no bubbles were observed during $5^{\prime} 24^{\prime \prime}$. Hereafter bubble release started and intensified from one outlet to over 23 outlets with increasing bubble rates and sizes (Figs. 9E-F, 10 ROV-7A and ROV-7A'). Overall bubble release from single outlets displayed a variety of patterns, from constant 

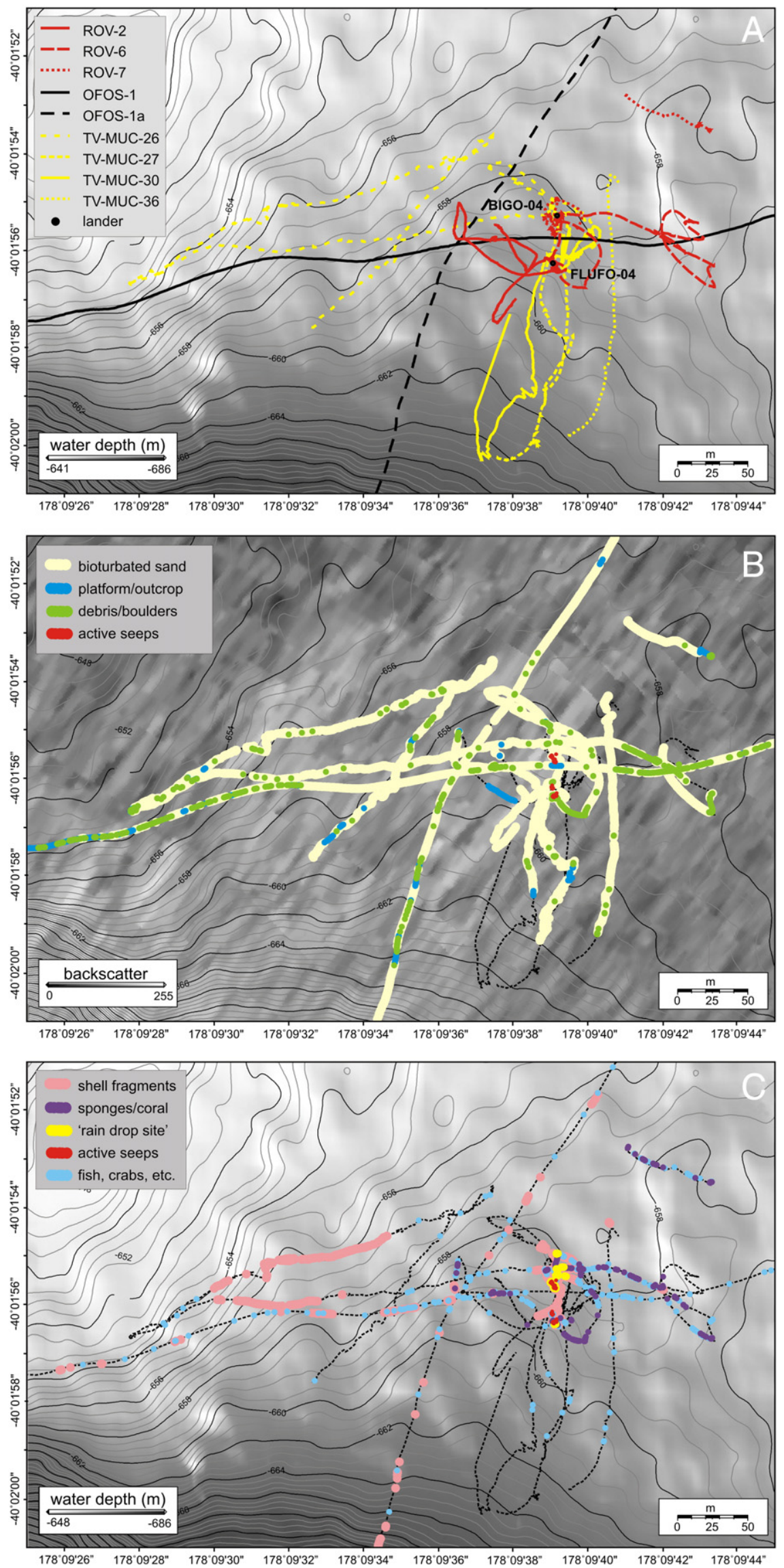

Fig. 8. Sea-floor observation maps at Faure Site with multibeam bathymetry (A and C) or backscatter (B) as background. A. Overview of the BIGO-04 and FLUFO-04 lander positions and ROV, OFOS and TV-MUC tracks. B. Sediment-type distribution. C. Fauna distribution. 

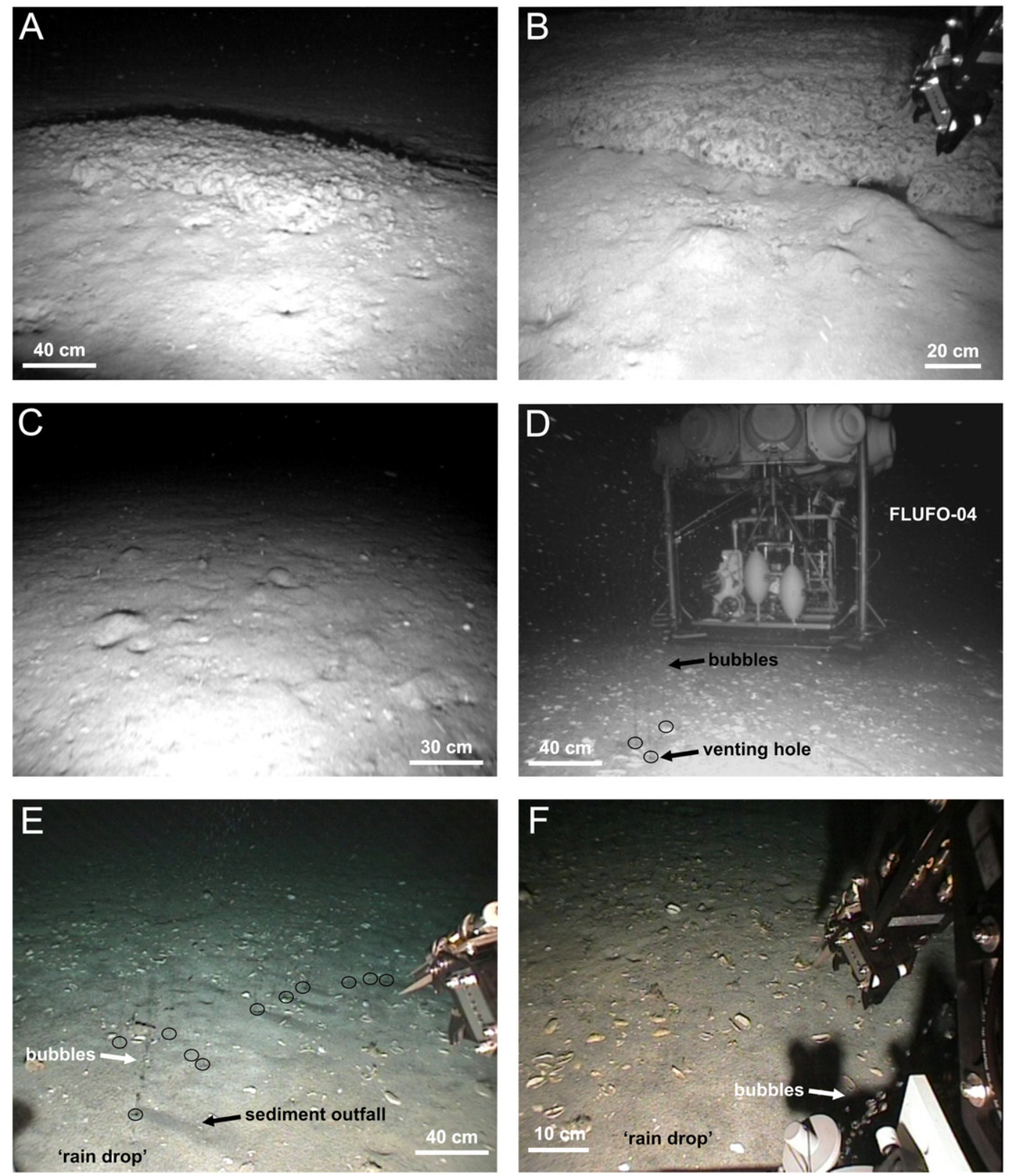

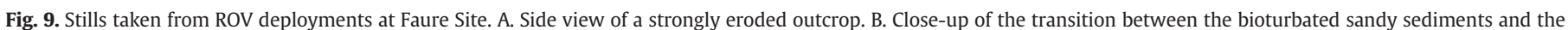

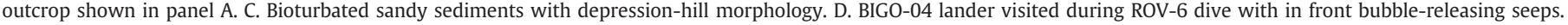
E. Alignment of bubble-releasing outlets at a 'rain drop site'. F. Bottom-water sampling at one of the active seeps seen in panel E.

single-bubble trains over dual or triple bubble release, to multiple bubble release during outbursts. The bubble patterns not only changed during the period of observation, but could be different for two outlets in the same cluster, even if the outlets were only a few centimeters apart.

\subsection{Thermal measurements}

Bottom-water and sediment temperature measurements were performed with a ROV-mounted CTD and THP sensor during the ROV-5, ROV-6 and ROV-7 dives. At Faure Site, during ROV-6 and ROV-7, temperatures at the sea floor fluctuated between $6.814{ }^{\circ} \mathrm{C}$ and $6.909{ }^{\circ} \mathrm{C}$ and between $7.170{ }^{\circ} \mathrm{C}$ and $7.120^{\circ} \mathrm{C}$, respectively, for water depths of ca. $663 \mathrm{~m}$ (ROV depth at the sea floor). At LM-3, temperatures ranged from $6.437{ }^{\circ} \mathrm{C}$ to $6.598^{\circ} \mathrm{C}$ at ca. $915 \mathrm{~m}$ water depth (ROV depth at the sea floor). These temperature fluctuations were long-term (i.e. $0.5-1.5 \mathrm{~h}$ ) and appeared to be unrelated to the location and/or movement of the ROV (Fig. 11). Moreover, there was little or no difference between the bottom- water temperatures measured with the CTD and the sediment temperatures measured with the THP sensor (Fig. 11). It was only during ROV-5 dive, at a 'rain drop site' at LM-3, that a negative sediment-temperature anomaly of ca. $0.05^{\circ} \mathrm{C}$ was measured in comparison with near-bottom water temperature recorded with the CTD (Fig. 11). This difference in temperature is much larger than the CTD's and THP's accuracies, $0.002{ }^{\circ} \mathrm{C}$ and $0.007^{\circ} \mathrm{C}$ respectively.

\section{Discussion}

5.1. Differences in seep environment: diffusive versus bubble-released methane

Based on our visual observations, Faure Site and LM-3 seem to portray different seep environments and distinct past/current seep activity; nevertheless they also bear some resemblances. Both seep areas are local features, where bubble release occurs in bioturbated 

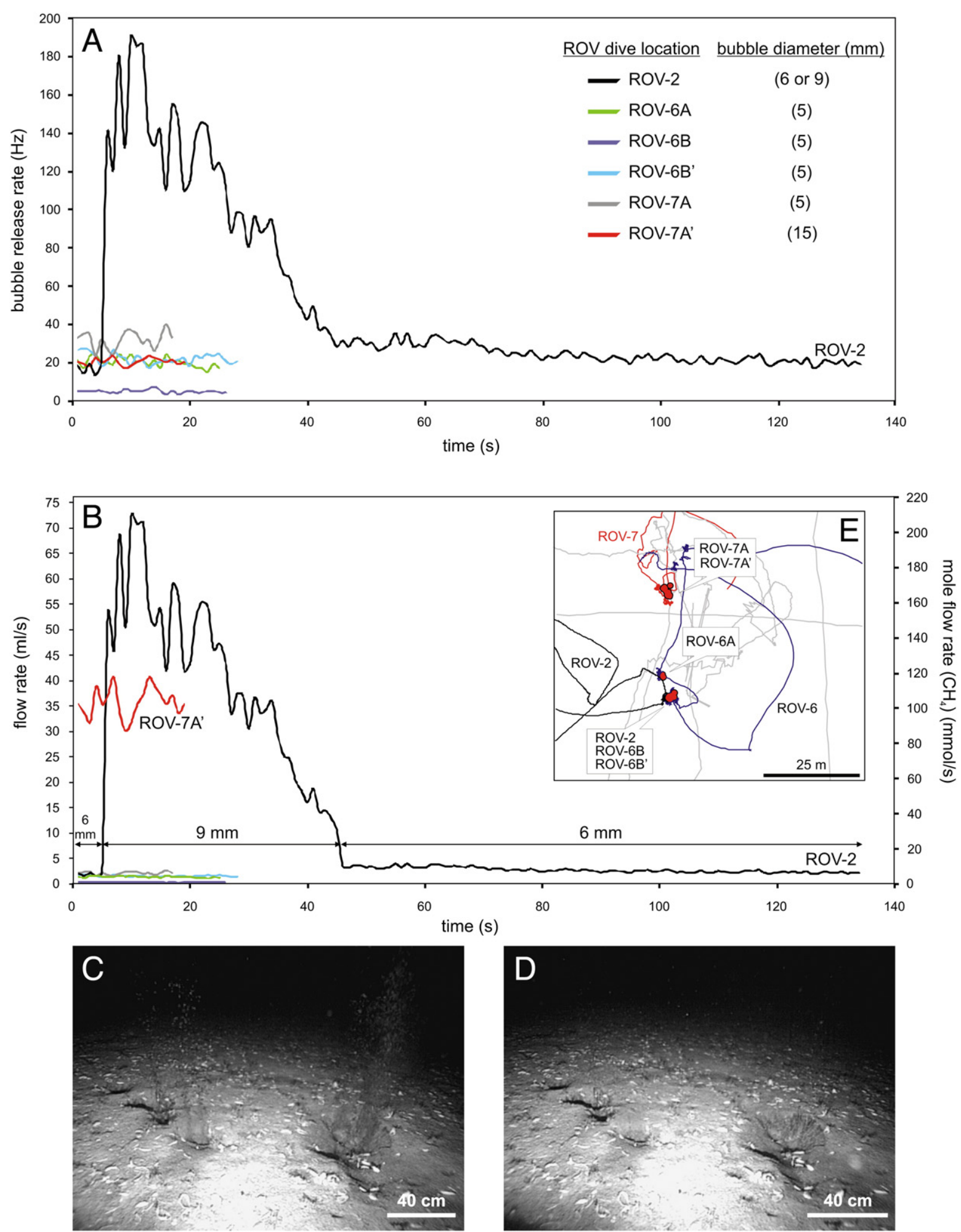

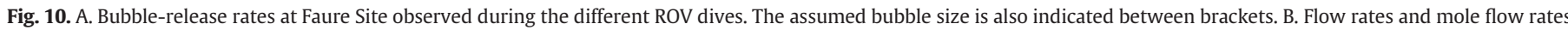

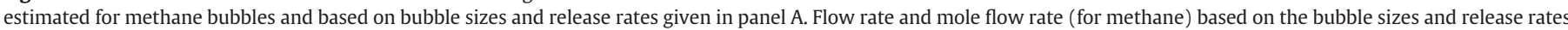

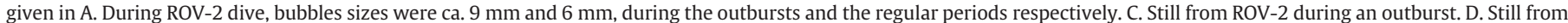
ROV-2 during a regular period. E. Schematic map showing the dive tracks, seep locations (red dots) and the locations of seep observation.

sandy sediments covered by dead Calyptogena sp. shells, and both are associated with ampharetid polychaetes near the bubble-releasing locations (Sommer et al., 2010-this issue) (Figs. 3-11). The seafloor at the LM-3 strongly differs from the rocky environment generally observed in the Northern Rock Garden area, whereas Faure Site rather blends in with the Western Rock Garden surroundings (Figs. 3 and 5). 

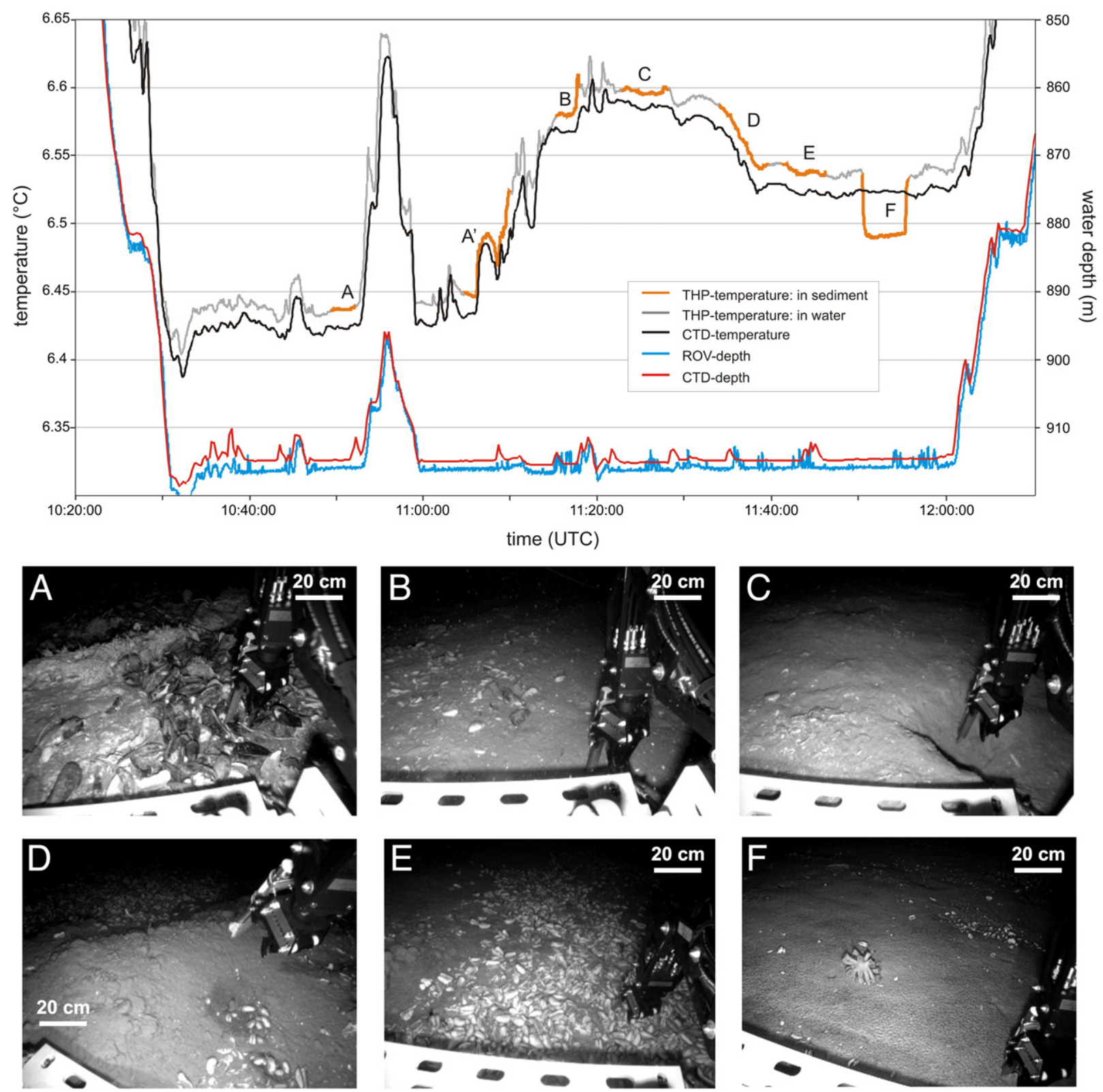

Fig. 11. Bottom-water and sediment temperature measured during ROV-5 at LM-3. Stills A to F show the different locations where sediment temperatures were measured with the ROV-mounted THP sensor. A-A'. Top of the platform, in a live Bathymodiolus sp.bed. B. Sandy sea floor with Calyptogena sp. shell fragments. C. Depression with a depth of ca. $20 \mathrm{~cm}$. D. Dark reduced sediment on a hill feature. E. Calyptogena sp. shell hash F. A 'Rain drop site' with ampharetid polychaetes (Sommer et al., 2010-this issue). This location was characterized by a negative sediment-temperature anomaly (see graph Fig. 11).

The major differences between both seep environments are:

- the presence of a relatively large $\left(100 \mathrm{~m}^{2}\right)$ platform-like structure composed of methane-derived carbonate (Campbell et al., 2010this issue) associated with live methane-related megafauna (Bathymodiolus sp. mussels and Lamellibrachia sp. tubeworms) and seemingly marginal bubble release at LM-3 (Figs. 3, 6 and 7);

- a very prominent bubble release, the absence of live methanerelated megafauna and the presence of semi-indurated and strongly bioturbated/eroded outcrops at Faure Site (Figs. 5, 8 and 9).

Based on these observations, we suggest that the differences observed between the two seep environments result from different methane release mechanisms: diffusive at LM-3 and mainly by bubble release at Faure Site.
The strong diffusive methane supply at LM-3 is clear from the presence of Bathymodiolus sp. mussels and Lamellibrachia sp. tubeworms, which are symbiont-bearing megafauna that strongly depend on a supply of dissolved methane or related sulfide (Brooks et al., 1987; Cary et al., 1988; Van Dover et al., 2003; Olu-Le Roy et al., 2004; Gay et al., 2006; Thurber et al., 2010-this issue). As this megafauna is located on a platform-like structure of methane-derived carbonate, which results from anaerobic oxidation of dissolved methane (AOM) (Campbell et al., 2010-this issue), a long-term, strong, diffusive input of methane into the sea-floor sediments at LM-3 can be inferred (Hovland et al., 1985; Paull et al., 1992; Peckmann et al., 2001; Orange et al., 2002; Greinert et al., 2002a; Johnson et al., 2003; Pape et al., 2005; Mazzini et al., 2006; Judd and Hovland, 2007). This inference is sustained by the very high methane concentrations of $16,542 \mathrm{nM}$, measured in water samples collected by the ROV ca. $50 \mathrm{~cm}$ above a field of live Bathymodiolus sp. mussels at the top of the carbonate platform (Faure et al., 2010-this issue). The concentric 
arrangement of the different habitats in this seep site, with high methane concentration and methane-depending megafauna surrounded by sulfide-depending megafauna, is very similar to seep areas observed in e.g. the Lower Congo Basin (Fig. 6) (Gay et al., 2006).

At Faure Site, visual observations have shown that bubble release is the dominant, albeit highly variable, methane-releasing process. The absence of fresh authigenic carbonate structures with live, methane-related megafauna also points to a bubble-release-controlled fluid system with very limited diffusive methane venting. The dominance of the bubble-transport mechanism is further sustained by high dissolved methane concentrations (up to $3500 \mathrm{nM}$ ) taken at ca. $10 \mathrm{~m}$ above the sea floor (Faure et al., 2010-this issue). These are the highest concentrations for all water samples taken from CTD casts at the Hikurangi Margin. These high methane concentrations so high in the water column can only be achieved through methane bubble release, as dissolved methane would most likely be consumed very effectively in the shallow sea-floor sediments and bottom waters by anaerobic and aerobic oxidation (Boetius et al., 2000; Boetius and Suess, 2004; Sommer et al., 2006 and 2010-this issue).

The presence of such a 'benthic filter' for the transfer of dissolved methane from the sediments and bottom waters to the water column is very clear at LM-3. It explains the discrepancy between the very high methane concentrations of $16,542 \mathrm{nM}$, obtained from water samples collected by the ROV just above the sea floor and the 'low' methane concentration of maximum $90 \mathrm{nM}$, measured in water samples taken during CTD casts only a few meters above the sea floor (Faure et al., 2010this issue). This pattern again indicates that methane release at LM-3 is mainly diffusive and release of methane by bubbles is rather insignificant.

The discussed difference in type of methane release between LM-3 and Faure Site, diffusive- versus bubble-released methane respectively, does not seem to influence the presence of ampharetid polychaetes ('rain drop sites') and suberitid sponges, which are live, seep-related fauna found at both seep sites (Campbell et al., 2010-this issue; Sommer et al., 2010-this issue; Thurber et al., 2010-this issue). The heterotrophic polychaetes mainly depend on aerobic oxidation of methane (AeOM) and do not seem to depend on strong AOM. The ampharetid polychaete beds together with the suberitid sponges seem to act as ecosystem engineers, which facilitate the transition from a soft sediment environment with mainly bubble release to a hard substrate seep environment with associated fauna where AOM and diffusive methane transport prevail (Sommer et al., 2010-this issue; Thurber et al., 2010-this issue).

The transport by large amounts of deep-derived fluids seems negligible at both sites since the sediment temperatures measurements were always comparable with the near-bottom water temperatures. At one 'rain drop site' at LM-3, a negative sediment temperature anomaly was measured. Colder sediment temperature in comparison with the near-bottom water temperature is opposite to what is expected at seepage sites. The negative temperature anomaly can be explained as a remnant of cold water infiltration induced by earlier gas bubble release through a process of recharge, as discussed by Poort et al. (2007). This could be plausible, since near-bottom water temperatures were indeed similar or colder in comparison to the anomalous sediment temperature measurements, ca. 40 min before the anomalous measurement (Fig. 11). The fact that this temperature anomaly was observed at a 'rain drop site' (and not in nearby measurements) suggests a relation with this specific habitat (Fig. 11) (Sommer et al., 2010-this issue). However, no temperature anomalies were observed at other 'rain drop sites' at Faure Site during ROV-6 and ROV-7. It is unclear whether the absence of such a negative sediment-temperature anomaly at the 'rain drop sites' at Faure Site could be related to differences in bubble-release rates in comparison with LM-3.

\subsection{Temporal variations in bubble-release activity}

Previous studies of bubble-release activity in seep areas have shown that bubble release is highly variable, both in space and in time
(Table 1) (Greinert et al., in review; Torres et al., 2002; Leifer and MacDonald, 2003; Sauter et al., 2006; Greinert et al., 2006; Nikolovska et al., 2008). Our ROV observations at the Hikurangi Margin confirm this general observation. During the three ROV dives at Faure Site, bubble release from three seep clusters was visually monitored over a total time of $80^{\prime} 31^{\prime \prime}$. Estimated bubble rates from single outlets ranged from 5 to 190 bubbles/s with bubble sizes ranging from $5 \mathrm{~mm}$ to over $15 \mathrm{~mm}$. This results in average flow rates of 0.018 to 2.4241 of methane/min, which corresponds to mole flow rates of 0.053 to $7.019 \mathrm{~mol} / \mathrm{min}$ at in situ conditions of $7{ }^{\circ} \mathrm{C}$ and 67.45 bar (Table 1 ). These values are comparable to published data from other seeps around the world (Table 1), although our bubble-size estimations were only based on ROV video footage. Compared to these other sites, the vent site monitored during ROV-2, ROV-6B and ROV-6B' dives at Faure Site can be regarded as the most variable one, portraying fluxes that differ up to two orders of magnitude. The differences in seep activity for seep sites elsewhere, as shown in Table 1, are related to observations of several seep clusters/sites or are estimation boundaries. The changing bubble-release activity seen during ROV-2 dive can be attributed to different controls over different time scales, from seconds to days. We suggest, that the long-term changes in bubblerelease activity, i.e. from periods without outburst (e.g. ROV-6B and ROV-6B') to periods with outbursts (ROV-2 dive), are probably related to external pressure changes (e.g. tides and changes in current directions) (Linke et al., 2010-this issue; Boles et al., 2001; Torres et al., 2002; Newman et al., 2008). Linke et al. (2010-this issue) confirms the correlation between flare observations and tides at the Hikurangi Margin. For the short-term changes (e.g. alternation between outburst and low activity as seen during the ROV-2 dive) we suggest an relationship to internal pressure changes during the filling of a shallow subsurface reservoir that creates an overpressure situation leading to the observed outbursts (Leifer et al., 2004). The outbursts depressurize the seep system, so the pressure/reservoir can build/fill up again. The regularity of the outbursts/bubble release indicates that over a certain time the seep system (internal configuration, external pressure and gas supply) does not change. Changes in bubble-release rates (ROV-6B to ROV-6B') and bubble sizes (ROV-7A to ROV-7A') are probably caused by changes in gas supply, rather than pressure changes (Leifer et al., 2004). Based on our observations, we could not substantiate whether the three seep clusters observed at Faure Site belong to one gas reservoir or are two or three separated systems. Changes in the outlet geometry, like the observed pockmark formation, could also affect bubble sizes and release rates, but this could not be confirmed or disproved by our observations. Whether the depression-and-hill morphology, as seen at both Faure Site and LM-3, results in all cases from bubble release is doubtful (Figs. 7D and 9C). In most cases, they are probably burrows made by crabs or fish (Gerino et al., 1995).

\subsection{An integrative seep model}

The different aspects of Faure Site and LM-3 probably results from different methane release mechanisms; bubbles versus diffusive fluid flow respectively (see Section 5.1). To explain what causes these differences in gas release, we propose an integrative model, taking into account the water depth, the depth of the BGHSZ and the observed sea-floor features (morphology, fauna, authigenic carbonates, bubble release, etc.) (Fig. 12).

The strong bubble release and the observed seep environment at Faure Site is a result of water depth $(659 \mathrm{~m})$ and the related shallow subsurface depth of the BGHSZ/BSR $(<35 \mathrm{~m}$ ) (Fig. 2c-c'). High gas concentrations present below the shallow BGHSZ allow gas (free and dissolved) to migrate towards the sea-floor surface rather easily, resulting in the observed gas venting (Figs. $2 \mathrm{c}-\mathrm{c}^{\prime}$ and 12 ). Crutchley et al. (2010-this issue) suggests that gas migrates along relatively permeable sedimentary layers (Fig. 12). Free gas is assumed to be able 
Table 1

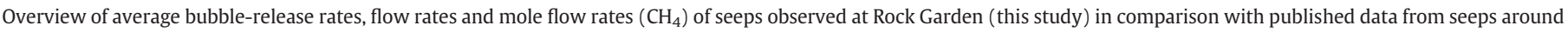

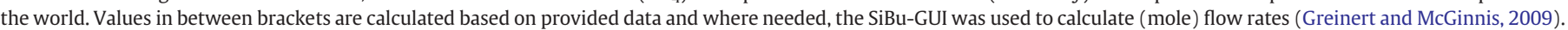

\begin{tabular}{|c|c|c|c|c|c|c|}
\hline \multirow[t]{2}{*}{ Location } & \multirow[t]{2}{*}{ Seep cluster } & \multirow{2}{*}{$\begin{array}{l}\text { Bubble-release rate } \\
(\mathrm{Hz})\end{array}$} & \multirow{2}{*}{$\frac{\text { Bubble size }}{(\mathrm{mm})}$} & \multirow{2}{*}{$\frac{\text { Flow rate per outlet }}{(1 / \mathrm{min})}$} & \multirow{2}{*}{$\begin{array}{l}\text { Mole flow rate per outlet } \\
\text { (mol/min) }\end{array}$} & \multirow[t]{2}{*}{ Outlets } \\
\hline & & & & & & \\
\hline $\begin{array}{l}\text { Pacific Ocean } \\
\text { Rock Garden } \\
\text { Faure Site }\end{array}$ & ROV-2 & 24 & 6 & 0.163 & 0.473 & 7 \\
\hline $\begin{array}{l}\text { Pacific Ocean } \\
\text { Rock Garden } \\
\text { Faure Site }\end{array}$ & ROV-2 & 106 & 9 & 2.424 & 7.019 & 13 \\
\hline $\begin{array}{l}\text { Pacific Ocean } \\
\text { Rock Garden } \\
\text { Faure Site }\end{array}$ & ROV-6A & 20 & 5 & 0.078 & 0.227 & 3 \\
\hline $\begin{array}{l}\text { Pacific Ocean } \\
\text { Rock Garden } \\
\text { Faure Site }\end{array}$ & ROV-6B & 5 & 5 & 0.018 & 0.053 & 1 \\
\hline $\begin{array}{l}\text { Pacific Ocean } \\
\text { Rock Garden } \\
\text { Faure Site }\end{array}$ & ROV-6B' & 22 & 5 & 0.084 & 0.242 & 2 \\
\hline $\begin{array}{l}\text { Pacific Ocean } \\
\text { Rock Garden } \\
\text { Faure Site }\end{array}$ & ROV-7A & 32 & 5 & 0.125 & 0.361 & $>23$ \\
\hline $\begin{array}{l}\text { Pacific Ocean } \\
\text { Rock Garden } \\
\text { Faure Site }\end{array}$ & ROV-7A' & 20 & 15 & 2.152 & 6.232 & $>23$ \\
\hline $\begin{array}{l}\text { Black Sea, } \\
\text { Dnepr paleo delta } \\
\text { (Greinert et al., in review) }\end{array}$ & Shelf & 36 & $2-16$ & $0.033-0.0864$ & 0.03 & 2709 \\
\hline $\begin{array}{l}\text { Black Sea, } \\
\text { Kobuleti Ridge } \\
\text { (Nikolovska et al., 2008) }\end{array}$ & Batumi seep & Not stated & $2-5$ & $0.01-5.5$ & $0.037-20.5$ & 10 \\
\hline $\begin{array}{l}\text { Gulf of Mexico } \\
\quad \text { (Leifer and MacDonald, 2003) }\end{array}$ & Bush Hill & Not stated & $1-20$ & $0.213-1.32$ & $0.453-3.192$ & 2 \\
\hline $\begin{array}{l}\text { Atlantic Ocean } \\
\text { Håkon Mosby Mud Volcano } \\
\text { (Sauter et al., 2006) }\end{array}$ & North of Center & $(558)$ & $1-10$ & $(0.64-2.85)$ & $4.8-21.6$ & 3 \\
\hline $\begin{array}{l}\text { Pacific Ocean } \\
\text { Hydrate Ridge } \\
\text { (Torres et al., 2002) }\end{array}$ & Northern summit & Not stated & Not stated & $1-5$ & (2.616-13.079) & 10 \\
\hline
\end{tabular}

to migrate in the GHSZ along gas-hydrate-coated veins that prevent additional hydrate formation due to limitation of water availability (Pecher et al., 2010-this issue). The migration of warmer or saline fluids will also favor free gas transport within the GHSZ (Ginsburg and Soloviev, 1997; Wood et al., 2002; Liu and Flemings, 2006). However, our observations and measurements (CTD and THP) do not point to migration of warmer or saline fluids to the sea floor. Furthermore, salt layers in the subsurface of Rock Garden are unlikely.

LM-3 is located at a greater depth of $908 \mathrm{~m}$. Together with the prevailing temperature, this situation results in a deeper subsurface depth of the BGHSZ/BSR of ca. $300 \mathrm{~m}$ (Figs. 2a-a' and 12) (Crutchley et al., 2010-this issue). Therefore a seemingly direct supply of free gas from beneath the BGHSZ towards the sea floor, as suggested for Faure Site, is significantly less likely. The free gas close to the sea floor was seismically detected in the GHSZ and is imaged as being 'spread out' (Crutchley et al., 2010-this issue). This pattern points to a lesser and not so intense focusing of the gas-charged fluids, and thus results in a more diffusive methane release at the seabed associated with authigenic carbonates, seep-related fauna and modest bubble release at LM-3. The modest bubble release at LM-3 does not counter this proposed model. The enhanced precipitation of methane-derived carbonates associated with AOM leads to both self-sealing of the LM-3 seep site and to methane accumulation underneath. When gas concentrations increase and reach supersaturation, bubbles can form and be released into the water column (Boudreau et al., 2001). The methane-driven carbonate cementation at the seafloor causes relocation of the actual bubble-releasing sites (Hovland, 2002; Naudts et al., 2008). This is indicated by the observed locations of the bubble release from sandy sediments away from the carbonate platform, just at the border of the high-backscatter area (Fig. 6). The self-sealing process is not complete, since a live methane-related megafauna is still present on the carbonate platform, and high methane concentrations were measured just above this site. Nevertheless, the selfsealing is already at an advanced stage, explaining the absence of live Calyptogena sp. The large amount of disarticulated Calyptogena sp. shells and the formation of the extensive carbonate platform $\left(100 \mathrm{~m}^{2}\right)$, however, do indicate that dissolved methane supply was high in the past and AOM was important during an early stage of the self-sealing process. We conclude that the seep site at LM-3, which is mainly diffusive at present, is relatively old in comparison with the seep site at Faure Site.

The "evolution" of Faure Site seems to be more complicated and therefore implies more speculation in our interpretation. At present, bubble release is certainly the main, but probably a relatively recent, methane-releasing mechanism (see Section 5.1). The presence of disarticulated Calyptogena sp. shells indicates that diffusive methane supply was more important in the past. This is also indicated by the presence of possible methane-derived carbonates and dead seep fauna in the area west of Faure Site, near the scarp of the submarine landslide (Figs. 2, 4E and 5A). We speculate that this change in methane-release mechanism can be explained in the context of the tectonic uplift of Rock Garden as the result of a subducting seamount (Pecher et al., 2005; Barnes et al., 2010-this issue; Ellis et al., 2010-this issue). The uplift of Rock Garden modified the depth of the GHSZ resulting in 1) a shallower BGHSZ and 2) more focused methane fluxes and 3) enhanced sea-floor destabilization (Ellis et al., 2010-this 


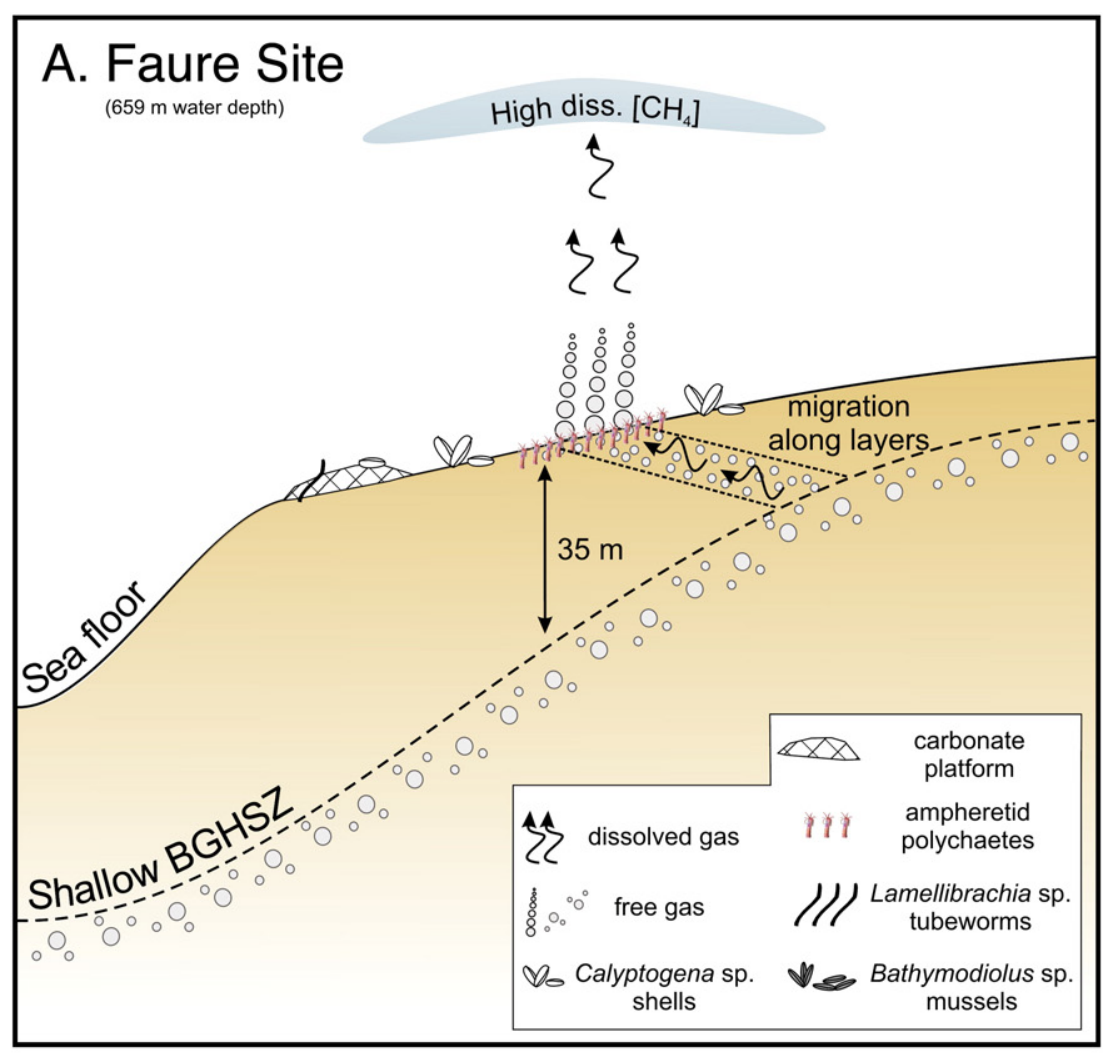

\section{B. LM-3 Site (908 $\mathrm{m}$ water depth)}

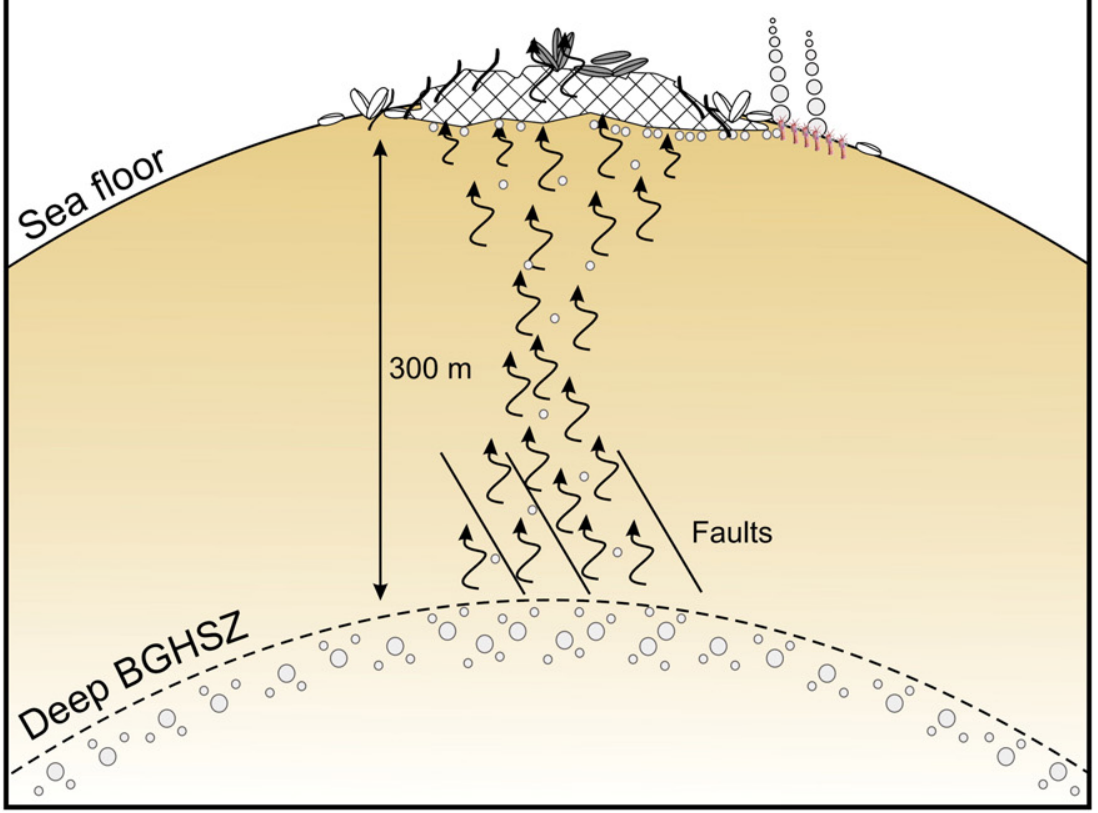

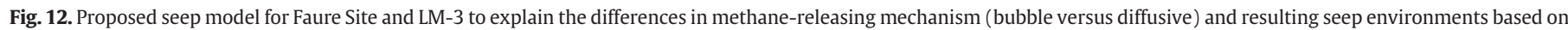
difference in depth, subsurface depth of the BGHSZ/BSR and observed sea-floor features.

issue). The latter is reflected in the large submarine landslide near Faure Site (Fig. 2) (Pecher et al., 2005; Faure et al., 2006). The associated occurrence of submarine landslides, shallow gas and seeps, whether or not in relation with gas hydrates, is a common feature at continental margins worldwide (Orange and Breen, 1992; Orange et al., 1997; Bouriak et al., 2000; Eichhubl et al., 2000; Bunz et al., 2005; Naudts et al., 2006). The close relation between seeps and scarps of submarine landslides can be explained by steepened pore- 
pressure gradients adjacent to scarps due to sudden erosion associated with slumping, and the resulting focusing of fluids towards the scarp areas (Orange et al., 1997; Naudts et al., 2006). The combination of tectonic uplift implying a shallower BGHSZ with a submarine landslide might have caused the change in methane release mechanism at Faure Site, from more diffusive in the past to bubble-release dominated at present.

\section{Conclusions}

ROV observations at Rock Garden allowed the first ever visual observation of bubble-releasing seeps at the Hikurangi Margin, and this at two sites; Faure Site and LM-3. The two seep areas portray different seep environments resulting from different types of methane release; mainly by bubble release at Faure Site and by diffusive release at LM-3. At Faure Site, bubble sizes (5-15 mm) and bubble-release rates $(5-190 \mathrm{~Hz})$ varied within minutes to hours, leading to variations in average mole flow rates per outlet of 0.018 $7.019 \mathrm{~mol}$ of methane/min. This is comparable with published data from bubble-releasing seeps around the world. Ampharetid polychaetes and suberitid sponges were the only live methane-related fauna observed at Faure Site. These organisms are ecosystem engineers facilitating the transition from a soft sediment environment with mainly bubble release to a hard substrate seep environment with associated fauna where AOM and diffusive methane transport prevail (Sommer et al., 2010-this issue; Thurber et al., 2010-this issue).

At LM-3, seep activity was confirmed by the occurrence of a large methane-derived carbonate platform $\left(100 \mathrm{~m}^{2}\right)$ covered with live seep-related mega fauna (Bathymodiolus sp. mussels and Lamellibrachia sp. tubeworms). Bubble release at LM-3 was rather modest, but was also associated with similar ecosystem-engineering fauna as observed at Faure Site. Based on the integration of all observations, a conceptual seep model is proposed that explains the differences in methane-releasing mechanisms and resulting seep environments based on differences in the depth of the BGHSZ and the different tectonic histories of the seep areas.

\section{Acknowledgements}

We would like to thank the captain and the crew of RV SONNE for their work during the third leg of the SO191 cruise. Jeroen Vercruysse and Wim Versteeg are gratefully thanked for getting ROV "Genesis" aka "Suzee" installed and working on RV SONNE. Jens Greinert thanks the EU for financial support and the possibility to work at GNS Science and RCMG via a Marie Curie Grant (MOIF-CT-2005-007436). Jeffrey Poort was supported by the Flemish Fund for Scientific Research (FWO-Flanders). Purchase of the ROV was possible thanks to an Impulsfinanciering of the Special Research Fund of Universiteit Gent. Participation to the expedition was co-financed by FWO-Flanders. This is publication Geotech-1228. Cruise S0191 was part of the COMET project in the framework of the R\&D program GEOTECHNOLOGIEN, both funded by the German Ministry of Education and Research (Grant No: 03G0600D and 03G0191A). Finally we thank Kathleen Campbell, Stéphanie Dupré and Keith Lewis for their constructive reviews which helped improve this manuscript.

\section{References}

Artemov, Y.G., Egorov, V.N., Polikarpov, G.G., Gulin, S.B., 2007. Methane emission to the hydro- and atmosphere by gas bubble streams in the Dnieper paleo-delta, the Black Sea. Mar. Ecol. J. 5-26.

Barnes, P.M., Lamarche, G., Bialas, J., Henrys, S., Pecher, I., Netzeband, G.L., Greinert, J. Mountjoy, J.J., Pedley, K., Crutchley, G., 2010. Tectonic and geological framework for gas hydrates and cold seeps on the Hikurangi subduction margin, New Zealand. Mar. Geol. $272,26-48$ (this issue).

Boetius, A., Ravenschlag, K., Schubert, C.J., Rickert, D., Widdel, F., Gieseke, A. Amann, R., Jorgensen, B.B., Witte, U., Pfannkuche, O., 2000. A marine microbial consortium apparently mediating anaerobic oxidation of methane. Nature 407 , 623-626.

Boetius, A., Suess, E., 2004. Hydrate Ridge: a natural laboratory for the study of microbial life fueled by methane from near-surface gas hydrates. Chem. Geol. 205, 291-310.

Boles, J.R., Clark, J.F., Leifer, I., Washburn, L., 2001. Temporal variation in natural methane seep rate due to tides, Coal Oil Point area, California. J. Geophys. Res. Oceans 106, 27077-27086.

Boudreau, B.P., Gardiner, B.S., Johnson, B.D., 2001. Rate of growth of isolated bubbles in sediments with a diagenetic source of methane. Limnol. Oceanogr. 46, 616-622.

Bouriak, S., Vanneste, M., Saoutkine, A., 2000. Inferred gas hydrates and clay diapirs near the Storegga Slide on the southern edge of the Voring Plateau, offshore Norway. Mar. Geol. 163, 125-148.

Brooks, J.M., Kennicutt, M.C., Fisher, C.R., Macko, S.A., Cole, K., Childress, J.J., Bidigare, R.R., Vetter, R.D., 1987. Deep-sea hydrocarbon seep communities - evidence for energy and nutritional carbon-sources. Science 238, 1138-1142.

Bunz, S., Mienert, J., Bryn, P., Berg, K., 2005. Fluid flow impact on slope failure from 3D seismic data: a case study in the Storegga Slide. Basin Res. 17, 109-122.

Campbell, K.A., Nelson, C.S., Alfaro, A.C., Boyd, S., Greinert, J., Nyman, S.L., Grosjean, E., Logan, G.A., Gregory, M.R., Cooke, S., Linke, P., Milloy, S., Wallis, I., 2010. Geological imprint of methane seepage on the seabed and biota of the convergent Hikurangi Margin, New Zealand: Box core and grab carbonate results. Mar. Geol. 272, 285-306 (this issue).

Cary, S.C., Fisher, C.R., Felbeck, H., 1988. Mussel growth supported by methane as sole carbon and energy-source. Science 240, 78-80.

Coleman, D., Ballard, R., 2001. A highly concentrated region of cold hydrocarbon seeps in the southeastern Mediterranean Sea. Geo. Mar. Lett. 21, 162-167.

Crutchley, G.J., Pecher, I.A., Gorman, A.R., Henrys, S.A., Greinert, J., 2010. Seismic imaging of gas conduits beneath seafloor seep sites in a shallow marine gas hydrate province, Hikurangi Margin, New Zealand. Mar. Geol. 272, 114-126 (this issue).

Eichhubl, P., Greene, H.G., Naehr, T., Maher, N., 2000. Structural control of fluid flow: offshore fluid seepage in the Santa Barbara Basin California. J. Geochem. Explor. 69, 545-549.

Ellis, S., Pecher, I., Kukowski, N., Xu, W., Henrys, S., Greinert, J., 2010. Testing proposed mechanisms for seafloor weakening at the top of gas hydrate stability on an uplifted submarine ridge (Rock Garden), New Zealand. Mar. Geol. 272, 285-306 (this issue).

Faure, K., Greinert, J., Pecher, I.A., Graham, I.J., Massoth, G.J., De Ronde, C.E.J., Wright, I.C., Baker, E.T., Olson, E.J., 2006. Methane seepage and its relation to slumping and gas hydrate at the Hikurangi margin, New Zealand. N. Z. J. Geol. Geophys. 49, 503-516.

Faure, K., Greinert, J., Schneider von Deimling, J.S., McGinnis, D.F., Kipfer, R., Linke, P., 2010. Methane seepage along the Hikurangi Margin of New Zealand: Geochemicaland physical data from the water column, sea surface and atmosphere. Mar. Geol. 272, $170-188$ (this issue).

Fujikura, K., Kojima, S., Tamaki, K., Maki, Y., Hunt, J., Okutani, T., 1999. The deepest chemosynthesis-based community yet discovered from the hadal zone, $7326 \mathrm{~m}$ deep, in the Japan Trench. Mar. Ecol. Prog Ser. 190, 17-26.

Gay, A., Lopez, M., Ondreas, H., Charlou, J.L., Sermondadaz, G., Cochonat, P., 2006. Seafloor facies related to upward methane flux within a Giant Pockmark of the Lower Congo Basin. Mar. Geol. 226, 81-95.

Gay, A., Lopez, M., Berndt, C., Seranne, M., 2007. Geological controls on focused fluid flow associated with seafloor seeps in the Lower Congo Basin. Mar. Geol. 244, 68-92.

Gerino, M., Stora, G., Poydenot, F., Bourcier, M., 1995. Benthic fauna and bioturbation on the Mediterranean continental slope: Toulon Canyon. Cont. Shelf Res. 15, 1483-1496.

Ginsburg, G.D., Soloviev, V.A., 1997. Methane migration within the submarine gashydrate stability zone under deep-water conditions. Mar. Geol. 137, 49-57.

Greinert, J., 2008. Monitoring temporal variability of bubble release at seeps: the hydroacoustic swath system GasQuant. J. Geophys. Res. Oceans 113, 20.

Greinert, J., McGinnis, D.F., 2009. Single bubble dissolution model - the graphical user interface SiBu-GUI. Environ. Model. Softw. 24, 1012-1013.

Greinert, J., Bohrmann, G., Elvert, M., 2002a. Stromatolitic fabric of authigenic carbonate crusts: result of anaerobic methane oxidation at cold seeps in $4850 \mathrm{~m}$ water depth. Int. J. Earth Sci. 91, 698-711.

Greinert, J., Bollwerk, S.M., Derkachev, A., Bohrmann, G., Suess, E., 2002b. Massive barite deposits and carbonate mineralization in the Derugin Basin, Sea of Okhotsk: precipitation processes at cold seep sites. Earth Planet. Sci. Lett. 203, 165-180.

Greinert, J., Artemov, Y., Egorov, V., De Batist, M., McGinnis, D., 2006. 1300-m-high rising bubbles from mud volcanoes at $2080 \mathrm{~m}$ in the Black Sea: hydroacoustic characteristics and temporal variability. Earth Planet. Sci. Lett. 244, 1-15.

Greinert, J., Lewis, K.B., Bialas, J., Pecher, I.A., Rowden, A., Bowden, D.A., De Batist, M., Linke, P., 2010. Methane seepage along the Hikurangi Margin, New Zealand: Overview of studies in 2006 and 2007 and new evidence from visual, bathymetric and hydroacoustic investigations. Mar. Geol. 272, 6-25 (this issue).

Greinert, J., McGinnis, D.F., Naudts, L., Linke, P., De Batist, M., in review. Atmospheric methane flux from bubbling seeps: spatially extrapolated quantification from a Black Sea shelf area. J. Geophys. Res.

Henrys, S.A., Ellis, S., Uruski, C., 2003. Conductive heat flow variations from bottomsimulating reflectors on the Hikurangi margin, New Zealand. Geophys. Res. Lett. 30, 1065-1068.

Hovland, M., 2002. On the self-sealing nature of marine seeps. Cont. Shelf Res. 22, 2387-2394.

Hovland, M., Talbot, M., Olaussen, S., Aasberg, L., 1985. Recently formed methanederived carbonates from the North Sea floor. In: B.M. Thomas (Editor), Petroleum Geochemistry in Exploration of the Norwegian Shelf. Norwegian Petroleum Society. Graham and Trotman, pp. 263-266.

Huetten, E., Greinert, J., 2008. Software controlled guidance, recording and postprocessing of seafloor observations by ROV and other towed devices: the software package OFOP. Geophys. Res. Abstr. 10, 03088. 
Jerosch, K., Schluter, M., Foucher, J.-P., Allais, A.-G., Klages, M., Edy, C., 2007. Spatial distribution of mud flows, chemoautotrophic communities, and biogeochemical habitats at Hakon Mosby Mud Volcano. Mar. Geol. 243, 1-17.

Johnson, J.E., Goldfinger, C., Suess, E., 2003. Geophysical constraints on the surface distribution of authigenic carbonates across the Hydrate Ridge region, Cascadia margin. Mar. Geol. 202, 79-120.

Judd, A., Hovland, M., 2007. Seabed Fluid Flow: The Impact on Geology, Biology and the Marine Environment. Cambridge University Press, Cambridge. 475 pp.

Judd, A., Croker, P., Tizzard, L., Voisey, C., 2007. Extensive methane-derived authigenic carbonates in the Irish Sea. Geo. Mar. Lett. 27, 259-267.

Judd, A.G., 2003. The global importance and context of methane escape from the seabed. Geo. Mar. Lett. 23, 147-154.

Katz, H.R., 1982. Evidence of gas hydrates beneath the continental-slope, East Coast, North Island, New Zealand. N. Z. J. Geol. Geophys. 25, 193-199.

Klaucke, I., Sahling, H., Weinrebe, W., Blinova, V., Burk, D., Lursmanashvili, N., Bohrmann, G., 2006. Acoustic investigation of cold seeps offshore Georgia, eastern Black Sea. Mar. Geol. 231, 51-67.

Leifer, I., Boles, J.R., Luyendyk, B.P., Clark, J.F., 2004. Transient discharges from marine hydrocarbon seeps: spatial and temporal variability. Environ. Geol. (Berlin) 46, 1038-1052.

Leifer, I., MacDonald, I., 2003. Dynamics of the gas flux from shallow gas hydrate deposits: interaction between oily hydrate bubbles and the oceanic environment. Earth Planet. Sci. Lett. 210, 411-424.

Lewis, K.B., Marshall, B.A., 1996. Seep faunas and other indicators of methane-rich dewatering on New Zealand convergent margins. N. Z. J. Geol. Geophys. 39, $181-200$.

Lewis, K.B., Collot, J.-Y., Lallem, S.E., 1998. The dammed Hikurangi Trough: a channelfed trench blocked by subducting seamounts and their wake avalanches (New Zealand-France GeodyNZ Project). Basin Res. 10, 441-468.

Linke, P., Sommer, S., Rovelli, L., McGinnis, D.F., 2010. Physical limitations of dissolved methane fluxes: The role of bottom boundary layer processes. Mar. Geol. 272, 209-222 (this issue).

Liu, X.L., Flemings, P.B., 2006. Passing gas through the hydrate stability zone at southern Hydrate Ridge, offshore Oregon. Earth Planet. Sci. Lett. 241, 211-226.

Mazzini, A., Svensen, H., Hovland, M., Planke, S., 2006. Comparison and implications from strikingly different authigenic carbonates in a Nyegga complex pockmark, G11, Norwegian Sea. Mar. Geol. 231, 89-102.

Naudts, L., Greinert, J., Artemov, Y., Staelens, P., Poort, J., Van Rensbergen, P., De Batist, M., 2006. Geological and morphological setting of 2778 methane seeps in the Dnepr paleo-delta, northwestern Black Sea. Mar. Geol. 227, 177-199.

Naudts, L., Greinert, J., Artemov, Y., Beaubien, S.E., Borowski, C., De Batist, M., 2008. Anomalous sea-floor backscatter patterns in methane venting areas, Dnepr paleodelta, NW Black Sea. Mar. Geol. 251, 253-267.

Newman, K.R., Cormier, M.-H., Weissel, J.K., Driscoll, N.W., Kastner, M., Solomon, E.A., Robertson, G., Hill, J.C., Singh, H., Camilli, R., Eustice, R., 2008. Active methane venting observed at giant pockmarks along the U.S. mid-Atlantic shelf break. Earth Planet Sci. Lett. 267, 341-352.

Nikolovska, A., Sahling, H., Bohrmann, G., 2008. Hydroacoustic methodology for detection, localization, and quantification of gas bubbles rising from the seafloor at gas seeps from the eastern Black Sea. Geochem. Geophys. Geosyst. 9.

Olu-Le Roy, K., Caprais, J.C., Fifis, A., Fabri, M.C., Galeron, J., Budzinsky, H., Le Menach, K., Khripounoff, A., Ondreas, H., Sibuet, M., 2007. Cold-seep assemblages on a giant pockmark off West Africa: spatial patterns and environmental control. Mar. Ecol. $28,115-130$.

Olu-Le Roy, K., Sibuet, M., Fiala-Médioni, A., Gofas, S., Salas, C., Mariotti, A., Foucher, J.-P., Woodside, J., 2004. Cold seep communities in the deep eastern Mediterranean Sea: composition, symbiosis and spatial distribution on mud volcanoes. Deep Sea Res. Part I: Oceanogr. Res. Pap. 51, 1915-1936.

Ondréas, H., Olu, K., Fouquet, Y., Charlou, J.L., Gay, A., Dennielou, B., Donval, J.P., Fifis, A., Nadalig, T., Cochonat, P., Cauquil, E., Bourillet, J.F., Moigne, M.L., Sibuet, M., 2005. ROV study of a giant pockmark on the Gabon continental margin. Geo. Mar. Lett. V25, 281-292.

Orange, D.L., Breen, N.A., 1992. The effects of fluid escape on accretionary wedges. 2. Seepage force, slope failure, headless submarine canyons, and vents. J. Geophys. Res. Solid Earth 97, 9277-9295.

Orange, D.L., McAdoo, B.G., Moore, J.C., Tobin, H., Screaton, E., Chezar, H., Lee, H., Reid, M., Vail, R., 1997. Headless submarine canyons and fluid flow on the toe of the Cascadia accretionary complex. Basin Res. 9, 303-312.
Orange, D.L., Yun, J., Maher, N., Barry, J., Greene, G., 2002. Tracking California seafloor seeps with bathymetry, backscatter and ROVs. Cont. Shelf Res. 22, 2273-2290.

Pape, T., Blumenberg, M., Seifert, R., Egorov, V.N., Gulin, S.B., Michaelis, W., 2005. Lipid geochemistry of methane-seep-related Black Sea carbonates. Palaeogeogr. Palaeoclimatol. Palaeoecol. 227, 31-47.

Paull, C.K., Chanton, J.P., Neumann, A.C., Coston, J.A., Martens, C.S., Showers, W., 1992 Indicators of methane-derived carbonates and chemosynthetic organic carbon deposits; examples from the Florida Escarpment. Palaios 7, 361-375.

Paull, C.K., Ussler Iii, W., Peltzer, E.T., Brewer, P.G., Keaten, R., Mitts, P.J., Nealon, J.W. Greinert, J., Herguera, J.-C., Elena Perez, M., 2007. Authigenic carbon entombed in methane-soaked sediments from the northeastern transform margin of the Guaymas Basin, Gulf of California. Deep Sea Res. Part II Top. Stud. Oceanogr. 54, 1240-1267.

Paull, C.K., Ussler, W., Greene, H.G., Barry, J., Keaten, R., 2005. Bioerosion by chemosynthetic biological communities on Holocene submarine slide scars. Geo. Mar. Lett. V25, 11-19.

Pecher, I.A., Henrys, S.A., Zhu, H., 2004. Seismic images of gas conduits beneath vents and gas hydrates on Ritchie Ridge, Hikurangi margin, New Zealand. N. Z. J. Geol. Geophys. 47, 275-279.

Pecher, I.A., Henrys, S.A., Ellis, S., Chiswell, S.M., Kukowski, N., 2005. Erosion of the seafloor at the top of the gas hydrate stability zone on the Hikurangi Margin, New Zealand. Geophys. Res. Lett. 32.

Pecher, I.A., Henrys, S.A., Wood, W.T., Kukowski, N., Crutchley, G.J., Forhmann, M., Kilner, J., Senger, K., Gorman, A.R., Coffin, R.B., Greinert, J., Faure, K., 2010. Focussed fluid flow on the Hikurangi Margin, New Zealand - Evidence from possible local upwarping of the base of the gas hydrate stability. Mar. Geol. 272, 99-113 (this issue).

Peckmann, J., Reimer, A., Luth, U., Luth, C., Hansen, B.T., Heinicke, C., Hoefs, J., Reitner, J. 2001. Methane-derived carbonates and authigenic pyrite from the northwestern Black Sea. Mar. Geol. 177, 129-150.

Poort, J., Kutas, R.I., Klerkx, J., Beaubien, S.E., Lombardi, S., Dimotrov, L., Vassilev, A. Naudts, L., 2007. Strong heat flow variability in an active shallow gas environment, Dnepr palaeo-delta, Black Sea. Geo. Marine Letters 27 (2-4), 185-195.

Sahling, H., Masson, D.G., Ranero, C.R., Huhnerbach, V., Weinrebe, W., Klaucke, I., Burk, D., Bruckmann, W., Suess, E., 2008. Fluid seepage at the continental margin offshore Costa Rica and southern Nicaragua. Geochem. Geophys. Geosystems 9, 22.

Sauter, E.J., Muyakshin, S.I., Charlou, J.-L., Schluter, M., Boetius, A., Jerosch, K., Damm, E., Foucher, J.-P., Klages, M., 2006. Methane discharge from a deep-sea submarine mud volcano into the upper water column by gas hydrate-coated methane bubbles. Earth Planet. Sci. Lett. 243, 354-365.

Schneider von Deimling, J.S., Brockhoff, J., Greinert, J., 2007. Flare imaging with multibeam systems: data processing for bubble detection at seeps. Geochem. Geophy. Geosystems 8.

Sommer, S., Linke, P., Pfannkuche, O., Niemann, H., Treude, T., 2010. Benthic respiration in a seep habitat dominated by dense beds of ampharetid polychaetes at the Hikurangi Margin (New Zealand). Mar. Geol. 272, 223-232 (this issue).

Sommer, S., Pfannkuche, O., Linke, P., Luff, R., Greinert, J., Drews, M., Gubsch, S., Pieper, M., Poser, M., Viergutz, T., 2006. Efficiency of the benthic filter: biological control of the emission of dissolved methane from sediments containing shallow gas hydrates at Hydrate Ridge. Glob. Biogeochem. Cycles 20.

Thurber, A.R., Kröger, K., Neira, C., Wiklund, H., Levin, L.A., 2010. Stable isotope signatures and methane use by New Zealand cold seep benthos. Mar. Geol. 272, 260-269 (this issue).

M.E.Torres, M.E., J.McManus, J., D.E.Hammond, D.E., M.A.de Angelis, M.A., K.U.Heeschen, K.U., S.L.Colbert, S.L., M.D.Tryon, M.D., K.M.Brown, K.M., E.Suess, E., 2002. Fluid and chemical fluxes in and out of sediments hosting methane hydrate deposits on Hydrate Ridge, OR, I: Hydrological provinces. Earth Planet. Sci. Lett. 201, 525-540.

Townend, J., 1997. Estimates of conductive heat flow through bottom-simulating reflectors on the Hikurangi and southwest Fiordland continental margins, New Zealand. Mar. Geol. 141, 209-220.

Van Dover, C.L., Aharon, P., Bernhard, J.M., Caylor, E., Doerries, M., Flickinger, W., Gilhooly W., Goffredi, S.K., Knick, K.E., Macko, S.A., Rapoport, S., Raulfs, E.C., Ruppel, C., Salerno, J. L., Seitz, R.D., Sen Gupta, B.K., Shank, T., Turnipseed, M., Vrijenhoek, R., 2003. Blake Ridge methane seeps: characterization of a soft-sediment, chemo synthetically based ecosystem. Deep-Sea Res. Part I-Oceanogr. Res. Pap. 50, 281-300.

Wood, W.T., Gettrust, J.F., Chapman, N.R., Spence, G.D., Hyndman, R.D., 2002. Decreased stability of methane hydrates in marine sediments owing to phase-boundary roughness. Nature $420,656-660$. 